Article

\title{
Impact of the Enhanced Permeability and Retention (EPR) Effect and Cathepsins Levels on the Activity of Polymer-Drug Conjugates
}

\author{
Amit K. Rajora ${ }^{\dagger}$, Divyashree Ravishankar ${ }^{\dagger}$, Helen M. I. Osborn and Francesca Greco * \\ Reading School of Pharmacy, University of Reading, Whiteknights, Reading RG6 6AD, UK; \\ E-Mails: a.k.rajora@pgr.reading.ac.uk (A.K.R.); d.ravishankar@pgr.reading.ac.uk (D.R.); \\ h.m.i.osborn@reading.ac.uk (H.M.I.O.) \\ $\dagger$ These authors contributed equally to this work. \\ * Author to whom correspondence should be addressed; E-Mail: f.greco@reading.ac.uk; \\ Tel.: +44-118-378-8244; Fax: +44-118-378-6562.
}

Received: 19 February 2014; in revised form: 28 June 2014 / Accepted: 14 July 2014 /

Published: 20 August 2014

\begin{abstract}
Polymer-drug conjugates have demonstrated clinical potential in the context of anticancer therapy. However, such promising results have, to date, failed to translate into a marketed product. Polymer-drug conjugates rely on two factors for activity: (i) the presence of a defective vasculature, for passive accumulation of this technology into the tumour tissue (enhanced permeability and retention (EPR) effect) and (ii) the presence of a specific trigger at the tumour site, for selective drug release (e.g., the enzyme cathepsin B). Here, we retrospectively analyse literature data to investigate which tumour types have proved more responsive to polymer-drug conjugates and to determine correlations between the magnitude of the EPR effect and/or expression of cathepsin B. Lung, breast and ovarian cancers showed the highest response rate $(30 \%, 47 \%$ and $41 \%$, respectively for cathepsin-activated conjugates and 31\%,43\%,40\%, across all conjugates). An analysis of literature data on cathepsin content in various tumour types showed that these tumour types had high cathepsin content (up to $3835 \mathrm{ng} / \mathrm{mg}$ for lung cancer), although marked heterogeneity was observed across different studies. In addition, these tumour types were also reported as having a high EPR effect. Our results suggest that a pre-screening of patient population could bring a more marked clinical benefit.
\end{abstract}


Keywords: polymer-drug conjugate; enhanced permeability and retention effect; cathepsin; tumour microenvironment

\section{Introduction}

Polymer-drug conjugates (PDCs) are nano-sized drug delivery systems, in which one or more chemotherapeutic agent is covalently linked to a water-soluble polymer (Figure 1a) [1,2]. The main rationale for PDCs stems from their ability to passively accumulate into the tumour tissue by means of the enhanced permeability and retention (EPR) effect (Figure 1b) [3]. This is a unique feature of tumour vasculature, which makes the tumour vasculature hyper-permeable to macromolecules compared to normal vasculature. As a result, PDCs have been shown to: (a) selectively target tumour tissues; (b) be less toxic and display an extended half-life compared to the parent free drug (e.g., maximum tolerated dose (MTD) for $N$-(2-hydroxypropyl)methacrylamide (HPMA) copolymer-doxorubicin $\left(320 \mathrm{mg} / \mathrm{m}^{2}\right)$ is four-fold higher than for the parent compound doxorubicin $\left.\left(60 \mathrm{mg} / \mathrm{m}^{2}\right)\right)[4]$.

Figure 1. (a) Schematic representation of a polymer-drug conjugate (PDC); (b) EPR effect facilitating passive tumour targeting of PDCs; and (c) Lysosomotropic delivery of PDC.

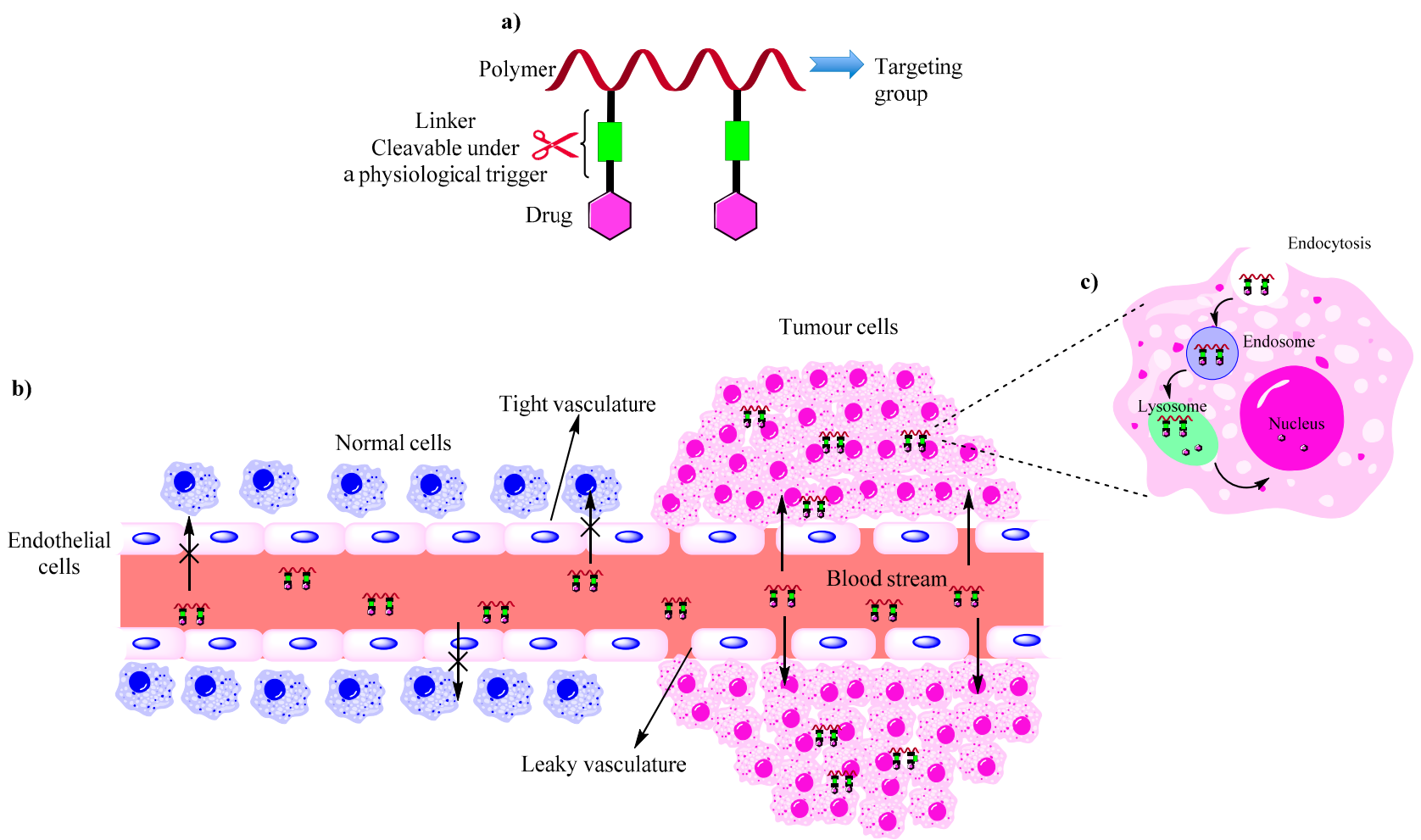

Nineteen PDCs have undergone/are undergoing clinical evaluation (Table 1 and Figure 2). Clinical trials have shown evidence of tumour responses to PDC to various degrees, and some conjugates (e.g., poly-L-glutamic acid (PGA)-paclitaxel) have progressed to Phase III trials [5,6]. In spite of several advantages of PDCs over the relevant parent drugs, such as a more favourable toxicity profile, superior 
quality of life and a significant survival rate [7], to date, no such conjugate has entered the market place, which suggests that system design and/or patient selection are still suboptimal.

When looking at possible reasons for the slow progression of the development of this technology, various factors need to be considered. First, PDCs are intrinsically more complex systems than low molecular weight drugs, for instance they have an inherent degree of variability due to the polydispersity of the carrier. In addition, and of greater significance, the anti-tumour activity of PDCs relies on two factors: (a) passive tumour accumulation via the EPR effect; (b) drug release following a biological stimulus (e.g., enzyme or pH) (Figure 1c). Failure to identify the correct patient/tumour type population, which displays a sufficient level of EPR effect and a sufficient level of enzymes, would negatively bias the results obtained with this technology.

Many studies have reported evidence for the EPR effect in a variety of solid tumours [8-11] but the factors that affect the magnitude of such an effect are still unclear. Recent studies have considered different in vivo tumour models and these have reported that both the size and tumour type can affect the magnitude of the EPR effect $[12,13]$. A discussion group constituted by world experts of the EPR effect has looked at the heterogeneity of such a phenomenon and has identified its key influencing factors, mainly: (a) the nature of the vascular bed and stroma, including the presence or absence of lymphatics; (b) tumour size, type and location; and (c) patient characteristics such as age, gender, body composition, and treatment $[10,13,14]$. With regards to expression of the various activating enzymes, again the situation is heterogeneous and unclear. It is well known that enzymes that have been exploited for activation of PDCs, such as cathepsin B, are expressed in tumour tissues [2,13,15-17]. However, it has been recently noted that various factors, such as hormone levels, can affect the abundance of such enzymes. For instance, cathepsin B levels are higher in pre-menopausal women than in post-menopausal women as the former have higher oestrogen levels than the latter $[5,18,19]$.

Table 1. Current clinical status of polymer-drug conjugates (PDCs) and types of release triggers.

\begin{tabular}{|c|c|c|c|c|c|}
\hline Release Trigger & Code/Product Name & Composition & Linker/Spacer & Status & Reference \\
\hline \multicolumn{6}{|l|}{ Enzymatic } \\
\hline Cathepsins & FCE28068/PK1 & HPMA copolymer-doxorubicin & Amide/Peptide ${ }^{\mathrm{d}}$ & Phase II & {$[4,20]$} \\
\hline Cathepsins & FCE28069/PK2 & $\begin{array}{l}\text { HPMA copolymer-doxorubicin- } \\
\text { galctosamine }\end{array}$ & Amide/Peptide ${ }^{d}$ & Phase I & [21] \\
\hline Cathepsins & DE-310 & Carboxymethyldextran-exatecan & Amide/Peptide ${ }^{\mathrm{d}}$ & Phase I & {$[22]$} \\
\hline Cathepsins & $\begin{array}{c}\text { Delimotecan } \\
\text { (MEN 4901/T-0128) }\end{array}$ & Carboxymethyldextran-T2513 & Triglycine & Phase I & [23] \\
\hline $\begin{array}{c}\text { Esterases/Acid } \\
\text { hydrolysis }^{\mathrm{a}} \\
\text { Cathepins }^{\mathrm{b}}\end{array}$ & CT-2106/PGA-CPT & PGA-camptothecin & Ester & Phase I & [24] \\
\hline $\begin{array}{l}\text { Esterases/Acid } \\
\text { hydrolysis }^{\mathrm{a}} \\
\text { Cathepins }^{\mathrm{b}}\end{array}$ & $\begin{array}{c}\text { CT-2103/PGA-PTX } \\
\text { XYOTAX }^{\mathrm{TM} /} \\
\text { OPAXIO }^{\circledR}\end{array}$ & PGA-paclitaxel & Ester & Phase III & $\begin{array}{l}{[5,6,19,} \\
25-34]\end{array}$ \\
\hline $\begin{array}{l}\text { Acid hydrolysis/ } \\
\text { Cathepsins }{ }^{c} \\
\end{array}$ & AP5280 & HPMA copolymer-carboplatinate & $\begin{array}{c}\text { Aminomalonate/ } \\
\text { Peptide }^{\mathrm{d}}\end{array}$ & Phase I/II & [35] \\
\hline
\end{tabular}


Table 1. Cont.

\begin{tabular}{|c|c|c|c|c|c|}
\hline Release Trigger & Code/Product Name & Composition & Linker/Spacer & Status & Reference \\
\hline $\begin{array}{c}\text { Acid hydrolysis/ } \\
\text { Cathepsins }^{c}\end{array}$ & AP5346/ProLindac ${ }^{\mathbb{R}}$ & $\begin{array}{l}\text { HPMA copolymer-DACH } \\
\text { oxiplatinate }\end{array}$ & $\begin{array}{c}\text { Aminomalonate/ } \\
\text { Peptide }^{\mathrm{e}}\end{array}$ & Phase I & {$[36]$} \\
\hline $\begin{array}{l}\text { Hydrolysis/ } \\
\text { Esterases }\end{array}$ & $\begin{array}{l}\text { PNU166945/ } \\
\text { HPMA-PTX }\end{array}$ & HPMA copolymer-paclitaxel & Ester & $\begin{array}{c}\text { Phase I } \\
\text { discontinued }\end{array}$ & {$[37]$} \\
\hline $\begin{array}{l}\text { Hydrolysis/ } \\
\text { Esterases }\end{array}$ & $\begin{array}{c}\text { PNU166148// } \\
\text { HPMA-CPT/MAG-CPT }\end{array}$ & HPMA copolymer-camptothecin & Ester & $\begin{array}{c}\text { Phase I } \\
\text { discontinued }\end{array}$ & {$[38-40]$} \\
\hline $\begin{array}{l}\text { Hydrolysis/ } \\
\text { Esterases }\end{array}$ & $\begin{array}{c}\text { EZN246/ } \\
\text { PEG-CPT/Pegamotecan/ } \\
\text { Prothecan }^{\mathrm{TM}}\end{array}$ & PEG-camptothecin & Ester & $\begin{array}{c}\text { Phase II } \\
\text { discontinued }\end{array}$ & [41-43] \\
\hline $\begin{array}{l}\text { Hydrolysis/ } \\
\text { Esterases }\end{array}$ & PEG-PTX & PEG-paclitaxel & Ester & $\begin{array}{c}\text { Phase I } \\
\text { discontinued }\end{array}$ & {$[44]$} \\
\hline $\begin{array}{l}\text { Hydrolysis/ } \\
\text { Esterases }\end{array}$ & $\begin{array}{l}\text { EZN-2208/ } \\
\text { PEG-SN-38 }\end{array}$ & PEG-SN-38 & Glycinamidoester & Phase II & {$[45,46]$} \\
\hline $\begin{array}{l}\text { Hydrolysis/ } \\
\text { Esterases }\end{array}$ & NKTR-102 & PEG-Irinotecan & Glycinamidoester & Phase II/III & {$[47-50]$} \\
\hline $\begin{array}{l}\text { Hydrolysis/ } \\
\text { Esterases }\end{array}$ & NKTR-105 & PEG-Docetaxel & - & Phase I & {$[51]$} \\
\hline $\begin{array}{l}\text { Hydrolysis/ } \\
\text { Esterases }\end{array}$ & XMT-1001 & PHF-camptothecin & Succinamidoester & Phase I & {$[52]$} \\
\hline Esterases & CRLX101/IT-101 & Cyclodextrin-camptothecin & Glycinamidoester & Phase II & [53] \\
\hline \multicolumn{6}{|l|}{ Non-enzymatic } \\
\hline \multirow[t]{2}{*}{$\mathrm{pH}$-sensitive } & ONCOFID-PTM & HA-paclitaxel & Hydrazone & Phase I/II & {$[54]$} \\
\hline & AD-70, DOX-OXD & Oxidised dextran-doxorubicin & Schiff's base & $\begin{array}{c}\text { Phase I } \\
\text { discontinued }\end{array}$ & {$[55]$} \\
\hline
\end{tabular}

Notes: ${ }^{a}$ Mediates the cleavage of the active drug from the polymeric backbone; ${ }^{b}$ Mediates the cleavage of the biodegradable polymeric backbone; ${ }^{\mathrm{c}}$ Mediates the cleavage of the peptide linker/spacer; ${ }^{\mathrm{d}}$ Spacer-Gly-Phe-Leu-Gly; e Spacer-Gly-Gly-Gly. HPMA, N-(2-Hydroxypropyl) methacrylamide; PGA, Poly-L-glutamic acid; PEG, Polyethylene glycol; PHF, Poly(1-hydroxyl-methylethylene hydroxyl-methyl-formal); HA, Hyaluronic acid.

In this paper, we retrospectively analyse data obtained from the literature concerning clinical trials carried out on PDCs in order to determine whether there is a connection between the clinical responses of various tumour types and the levels of enzyme expression/magnitude of the EPR effect in such tumour types. First, we analysed clinical data within the literature to identify the tumour types for which marked tumour responses were observed. Then, we documented the content of cathepsin B that has been reported for the various tumour types. Finally, we determined the extent of the EPR effect, which has been, reported for these various tumour types. 
Figure 2. Chemical structures of the PDCs discussed in this article. (a) PDCs for which the release of the drug is triggered via an enzymatic mechanism; and (b) PDCs for which the release of the drug is triggered by a non-enzymatic mechanism. Note: The chemical structure of NKTR-105 is not available.

(a)

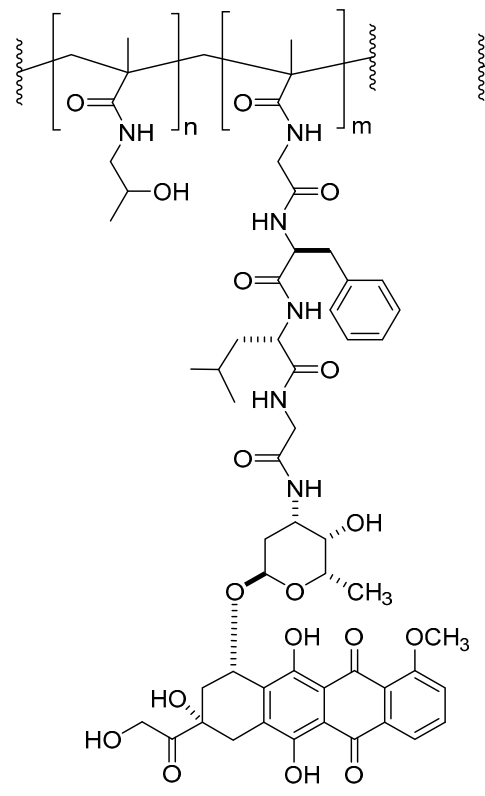

HPMA copolymer-doxorubicin (FCE28068)/PK-1

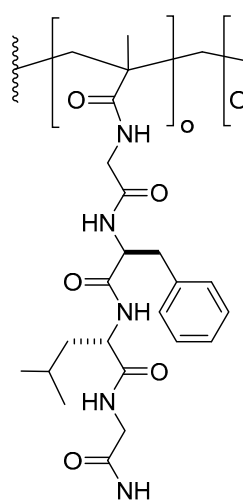

$\overbrace{\mathrm{OH}}^{\mathrm{OH}}$

$$
\mathrm{OH}
$$

(a)

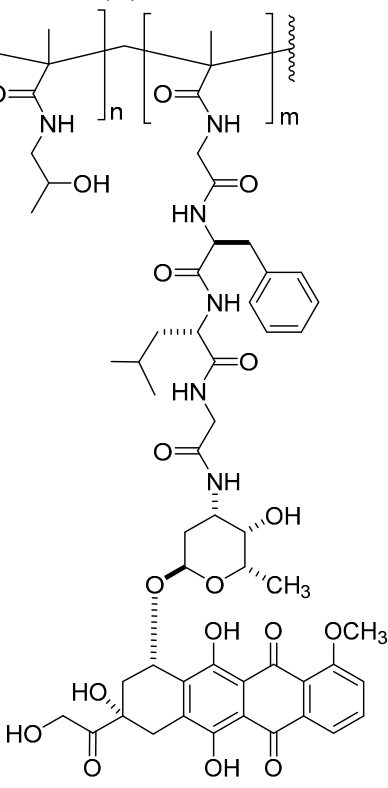

HPMA copolymer-doxorubicin-galactosamine (FCE28069)/PK-2

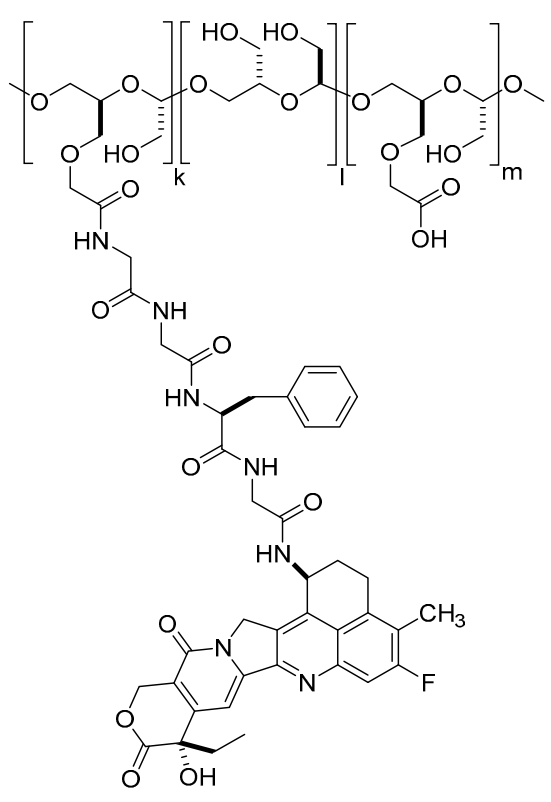

Carboxymethyldextran-exatecan (DE-310)
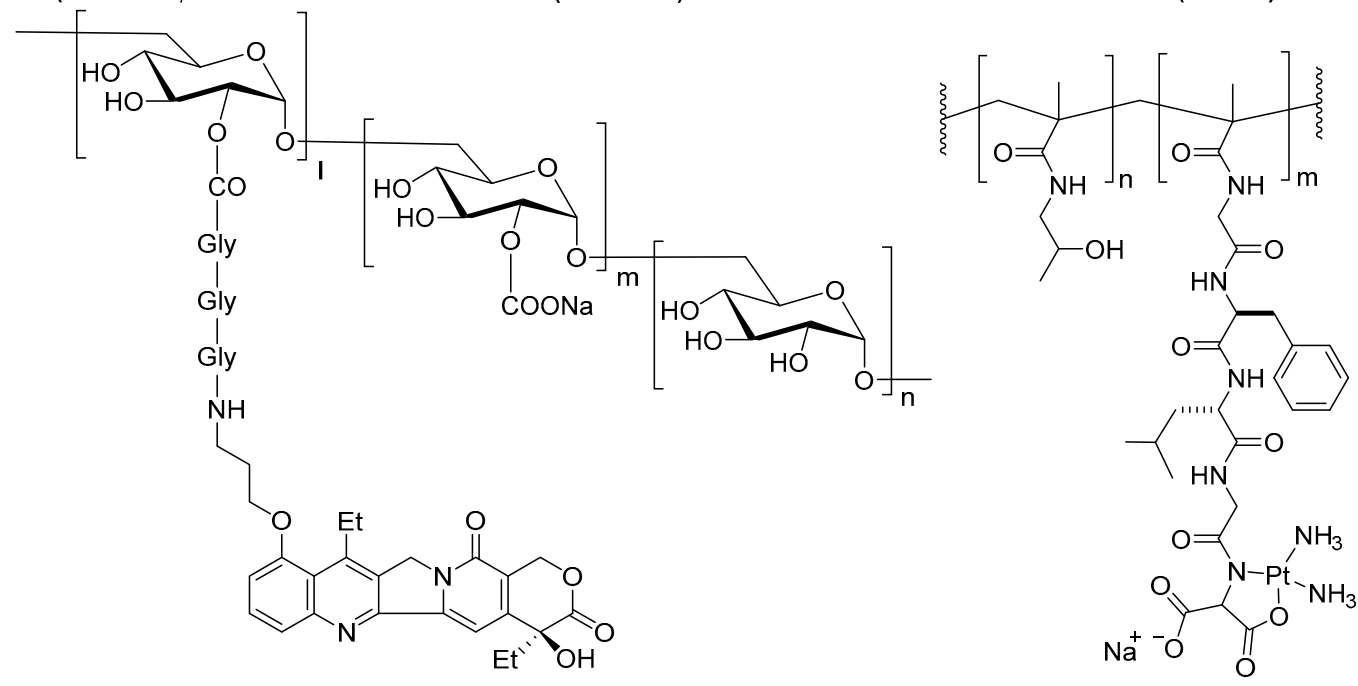

Carboxymethyldextran-T2513

HPMA copolymer-carboplatinate

Delimotecan/(MEN4901/T-0128)

(AP5280)

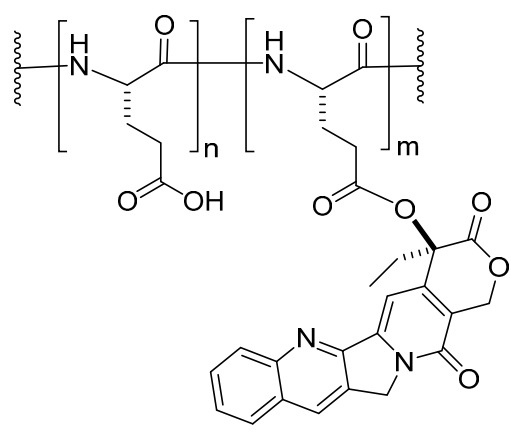<smiles>CC(C)C(=O)C(CC(=O)OC(C(=O)O)C(NC(=O)c1ccccc1)c1ccccc1)C(C)(C)C</smiles>

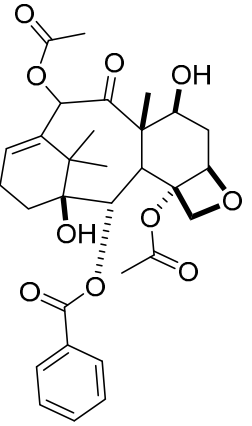


Figure 2. Cont.

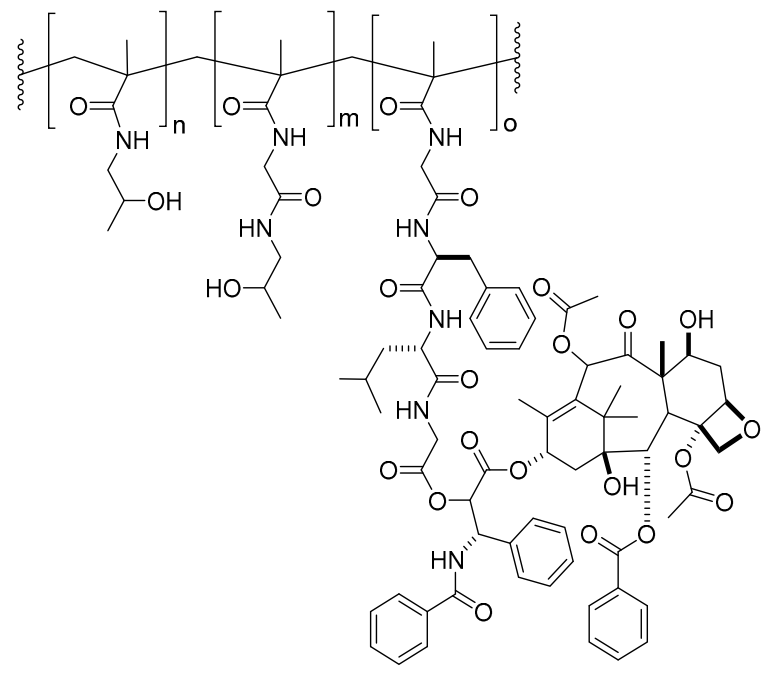

HPMA copolymer-paclitaxe (PNU16695)/HPMA-PTX
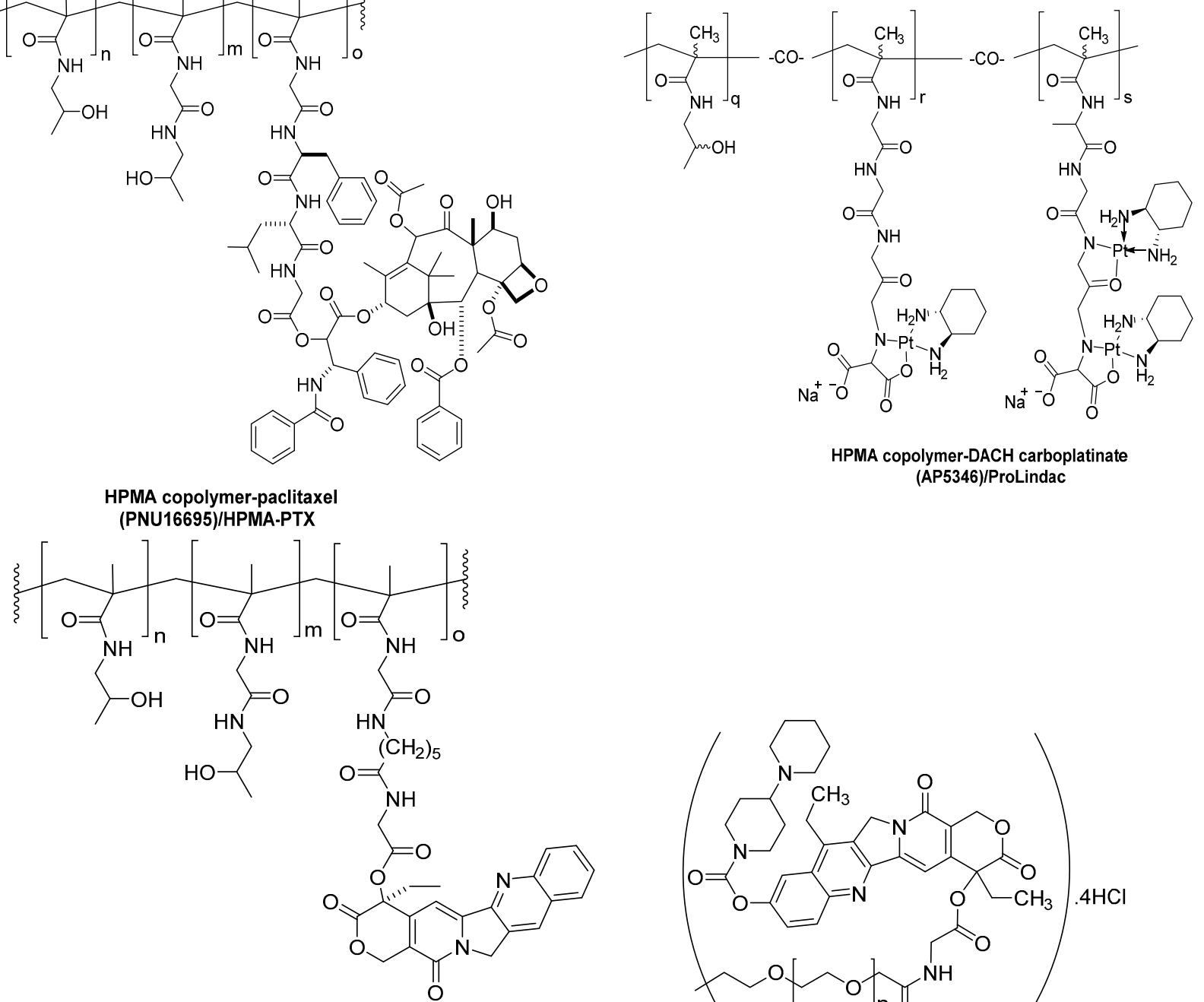

(AP5346)/ProLindac

HPMA copolymer-camptothecin (PNU166148)/HPMA-CPT/MGA-CPT

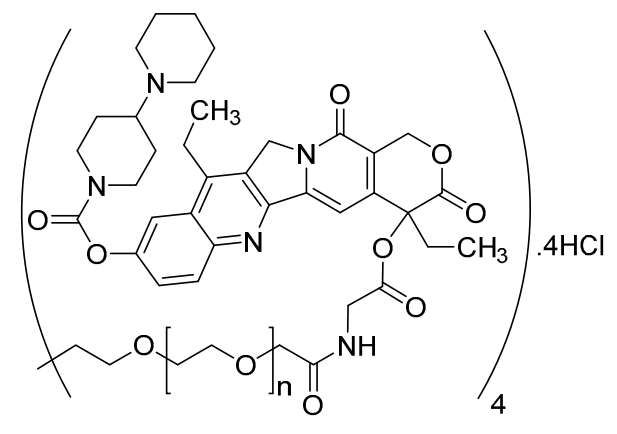

PEG-Irinotecan

(NKTR-102)
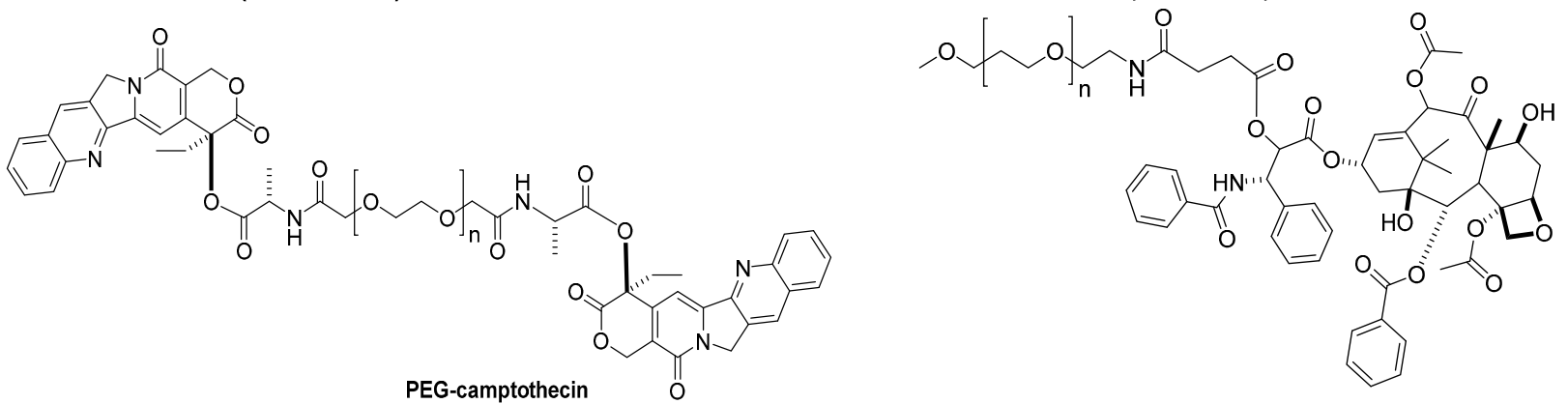

(EZN246)/PEG-CPT/Pegamotecan/Prothecan ${ }^{\mathrm{TM}}$

PEG-paclitaxel (PEG-PTX) 
Figure 2. Cont.

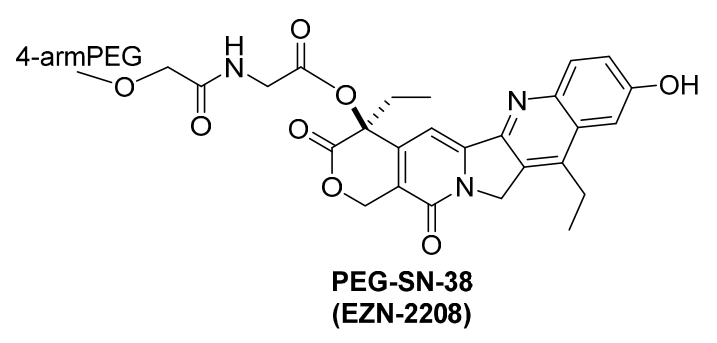

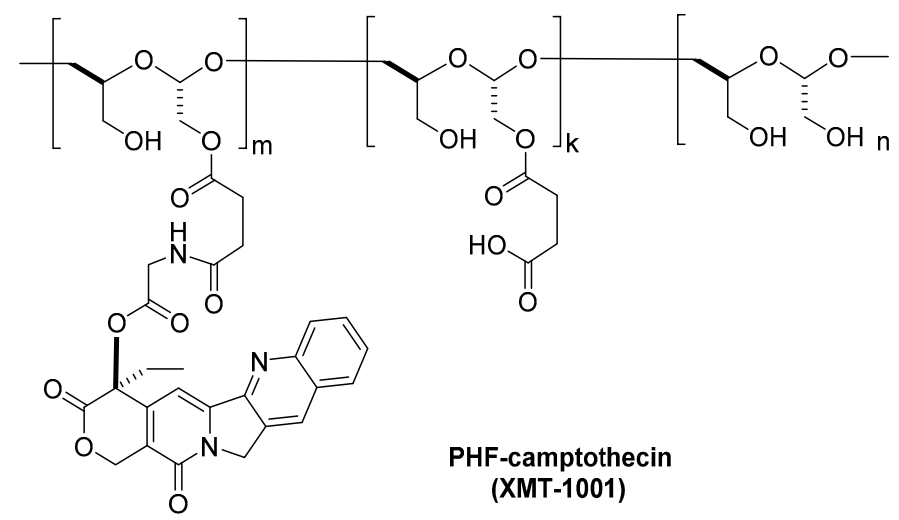

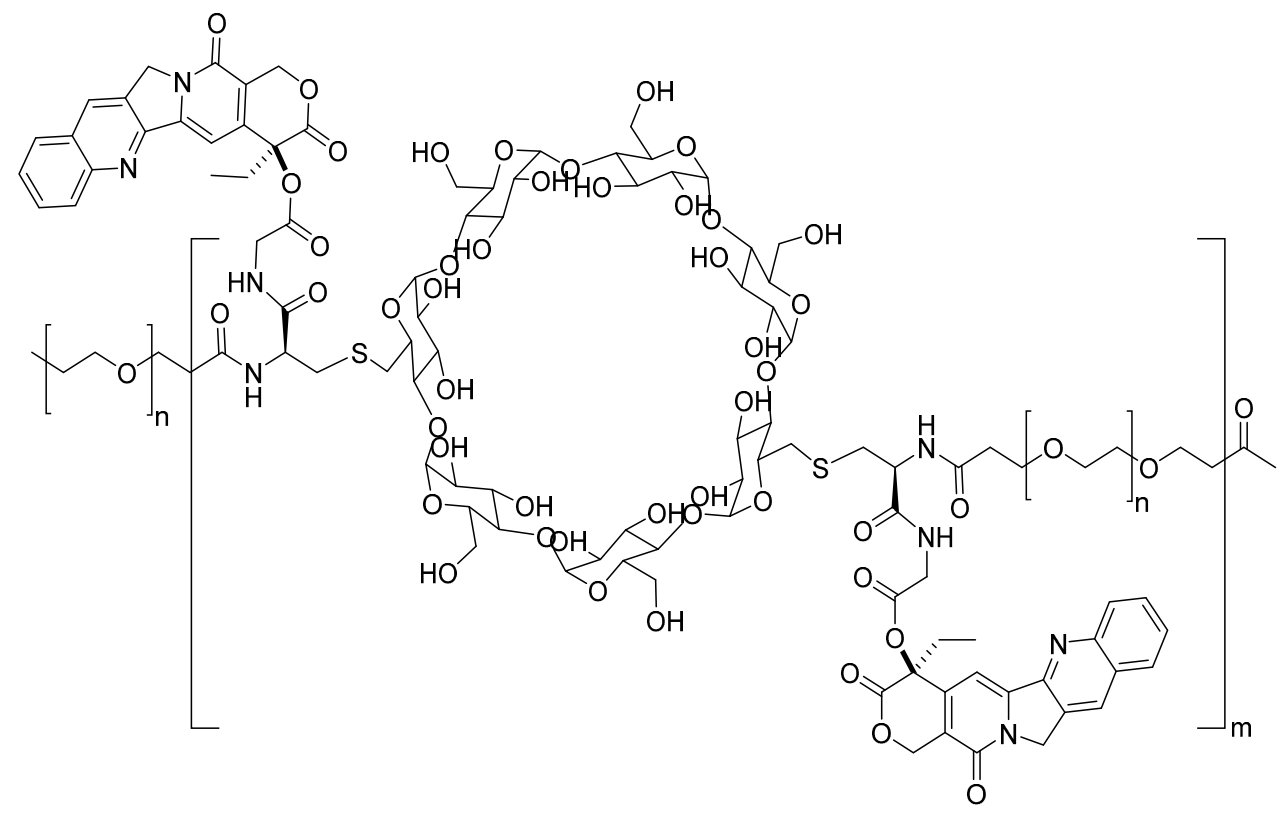

Cyclodextrin-camptothecin

(CLRX101)/IT-101

(b)
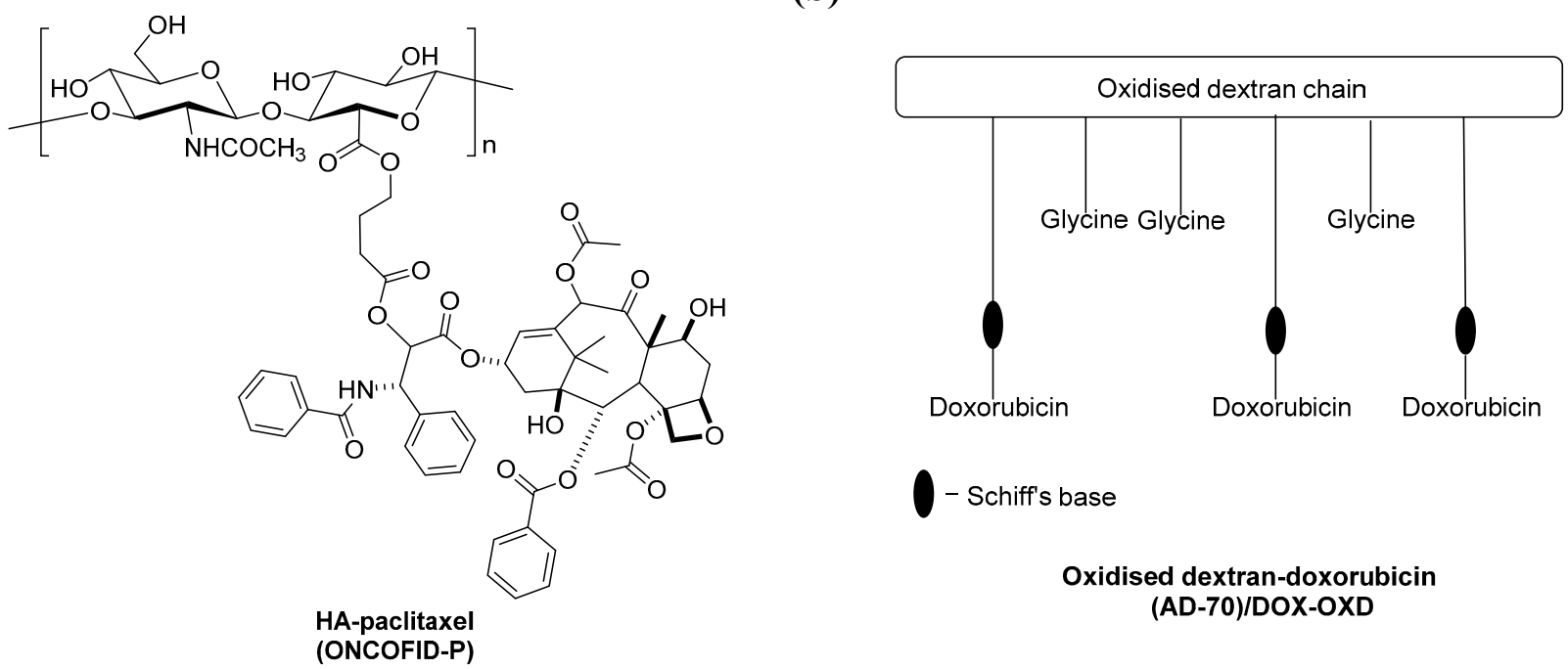


\section{Experimental Section}

The data presented in this paper were collected via systematic literature searches using search engines such as PubMed, Science Direct and Web of Science. No date restrictions were applied to the searches.

\subsection{Terminology}

This paper reports data collected from various sources that are derived from both clinical and pre-clinical studies. Different studies used different terminologies when referring to the various cancer types, with the terminologies ranging from technical/very specific (e.g., glioblastoma) to more general (e.g., brain cancer). In addition, in some cases, the effects of the tumours on adjacent organs are reported (e.g., gastroesophageal cancer). To ensure that a consistent terminology is used within this paper, clinical tumour types and preclinical models were grouped under general umbrella terms summarised in Table 2.

Table 2. Summary of the terminology used in this article to identify various tumour types/tumour models.

\begin{tabular}{|c|c|}
\hline $\begin{array}{l}\text { Tumour Type } \\
\text { (Terminology Used in This Article) }\end{array}$ & $\begin{array}{l}\text { Tumour Type } \\
\text { (Terminology Used in the Original Reference) }\end{array}$ \\
\hline Breast & $\begin{array}{l}\text { Breast, mammary gland, MCF-7, MDA-MB-231, BT } 20 \text { and DU4476-cell lines, } \\
\text { Walker 256-murine model, MX-1, MAXF 449-human xenograft. }\end{array}$ \\
\hline Colon and/or rectum & Colon, rectum, colorectal, anus, C26 NL-17, HT-29, LS174T-human xenograft. \\
\hline Head/Neck and brain & $\begin{array}{l}\text { Brain, glioblastoma, head/neck, thyroid, salivary gland, follicular, papillary, } \\
\text { tongue, maxillary sinus, parotid gland, IMR-32, SK-N-SH, } \\
\text { SK-N-DZ- human xenograft. }\end{array}$ \\
\hline Lung & $\begin{array}{l}\text { Non-small cell lung cancer, small cell lung cancer, bronchial, } \\
\text { Meta-7-murine model, H522, COR L23-human xenograft. }\end{array}$ \\
\hline Oesophagus, stomach and intestine & $\begin{array}{l}\text { Oesophageal, cardioesophageal, stomach, gastroesophageal, gastrointestinal, } \\
\text { intestine, small bowel, peritoneal carcinosis, OCUM-2MLN-human xenograft. }\end{array}$ \\
\hline Ovary & $\begin{array}{l}\text { Ovarian, Oca-1-murine model, A2780 cell line/human xenograft, SK-OV-3, } \\
\text { OVCAR-3-human xenograft. }\end{array}$ \\
\hline Pancreas & Pancreatic, PAXF 546-human xenograft. \\
\hline Skin & $\begin{array}{l}\text { Melanoma, basal cell, histosarcoma, B16F10, A431-murine model, } \\
\text { MEXF 276-human xenograft. }\end{array}$ \\
\hline Urinary & Bladder, urinary tract, urethal, urothelial, urachus. \\
\hline $\begin{array}{l}\text { Others: } \\
\text { The term indicates the tumour types } \\
\text { which were either studied in a very } \\
\text { low sample size }(n<3) \text { and/or those } \\
\text { for which low responses were } \\
\text { observed. }\end{array}$ & $\begin{array}{l}\text { Adrenal, adenoid cystic, adenocarcinoma (unknown primary), bone (ewing } \\
\text { sarcoma, osteosarcoma), cervix (uterine, leiomysarcoma uteri, ME180-human } \\
\text { xenograft), fibrosarcoma (S-180, Meth A-murine model), gall bladder, kidney, } \\
\text { leiomysarcoma, liver (cholangiocarcinoma, ampullary, bile duct, L1210-murine } \\
\text { model, VX-2 carcinoma), lymphoma, mesothelioma, neuroendocrine, prostrate, } \\
\text { sarcoma (unknown), soft tissue sarcoma, squamous cell sarcoma (unknown origin), } \\
\text { solid tumours (unknown), unknown primary tumours, MAC 15A-murine model, } \\
\text { MAC 26-murine model, RXF 486, RXF 1220, ME 180-human xenograft. }\end{array}$ \\
\hline
\end{tabular}




\subsection{Clinical Status of the PDCs}

The data on the current clinical status of the PDCs, reported in Table 1, were gathered from articles obtained using the key word "polymer-drug conjugate*". The clinical data related to each individual conjugate, which are reported in the supplementary information, were gathered using the name of the individual conjugate.

The percentage tumour response reported for each conjugate, per tumour type, was determined considering all of the clinical responses observed (i.e., number of (partial response (PR) + complete response $(\mathrm{CR})+$ stable disease $(\mathrm{SD})+$ minor responses $(\mathrm{MR}))$, as well as the total number of patients evaluated per tumour type using the following formula:

Response to conjugate $\mathrm{A}$ in tumour X $(\%)=($ Total clinical responses observed for conjugate $\mathrm{A}$ in tumour $\mathrm{X} /$

Number of patients evaluated for conjugate $\mathrm{A}$ in tumour $\mathrm{X}) \times 100$

The results obtained for each conjugate for each tumour type (reported in supplementary information, Tables S1 to S19) were then further processed in order to obtain an overall response to all PDCs per tumour type.

The overall percentage tumour response for each tumour type was determined using the following formula:

Overall response in tumour $\mathrm{X}(\%)=\Sigma[($ Response to conjugate $\mathrm{A}$ in tumour $\mathrm{X}(\%) \times$ number of patients with tumour $\mathrm{X}$ in which conjugate $\mathrm{A}$ was tested $)+($ Response to conjugate $\mathrm{B}$ in tumour $\mathrm{X}(\%) \times$ number of patients with tumour $\mathrm{X}$ in which conjugate $\mathrm{B}$ was tested $)+$ (Response to conjugate $n$ in tumour $\mathrm{X}(\%) \times$ number of patients with tumour $\mathrm{X}$ in which conjugate $n$ was tested)]/Total number of patients with tumour $\mathrm{X}$

\subsection{Cathepsin Level}

The data on cathepsin levels in various tumour types were collected via literature searches using the following key words and their combinations: "cathepsin level*", "cathepsin content*", "tumour/tumor types".

\subsection{EPR Effect}

The data related to the EPR effect in different tumour types were retrieved via literature searches using the following key words (and their combinations): "enhanced permeability and retention effect", "EPR effect", "tumour/tumor*”, "drug accumulation", "biodistribution" and the names of the individual conjugates. In addition, original research articles quoted in reviews related to the EPR effect, which were not identified from the general search, were also considered.

Priority was given to articles related to PDCs, however, as the EPR effect is a phenomenon that applies to any macromolecular system, clinical and preclinical data relating to other such systems (e.g., liposomes and micelles) were also included. 


\section{Results and Discussion}

Many clinical studies have been carried out on PDCs (e.g., OPAXIO) [26]. The main clinical outcomes have been summarized in extensive reviews [55-57], but, as yet, a detailed analysis of which tumour types are proving more responsive to this type of drug delivery technology is still missing. A number of studies have already attempted to identify correlations between tumour types and enzyme content or the magnitude of the EPR effect, but this approach has been largely carried out in preclinical models and systematic assessments of these factors and clinical activities are missing, which is surprising since the latter are two key pre-requisites for the activity of PDCs.

In an attempt to provide a more comprehensive study that links clinical outcomes, enzyme content, and the EPR effect, we initially documented all the PDCs that have been explored in clinical trials, alongside the triggers that have been used to promote drug release in each (Table 1). Of the 19 conjugates that have been tested in patients, the vast majority (17) rely, at least partially, on the presence of enzymes for drug release (Table 1). Of the various enzymes exploited as triggers, cathepsins, a family of lysosomal proteases, are the most widely targeted (eight of the conjugates reported in Table 1 rely on cathepsins action for drug release). This is not surprising, as cathepsins have been reported to be linked with cancer progression. In particular, cathepsin B has been connected with tumour invasion [58].

\subsection{Effect of Tumour Type on Clinical Response}

To assess the clinical responses observed in different tumour types, we analysed clinical data for PDCs retrieved from our literature searches. Although the purpose of phase I, II and III clinical trials and their patient selection criterias are different, the objective responses (i.e., partial response (PR), complete response (CR), stable disease (SD) and minor responses (MR)) are considered as the end point in all such studies [59]. Therefore for each conjugate, evidence of a clinical response (PR, CR SD and MR) in the various tumour types has been summarised in detail in Tables S1-S19 in the supplementary information. A representative data set with clinical responses for the top three highest responsive tumour types for each conjugate has been provided in Table 3. For example, in the case of HPMA copolymer-doxorubicin (PK1; FCE28068), the top three highest responsive tumour types are lung, breast, colon and/or rectum, with tumour responsive rate of $57 \%, 53 \%$, and $4 \%$, respectively calculated from both phase II clinical trials and I. Likewise, the top three highest responsive tumour types based on the calculation from all the available clinical phase trials have been summarised for the other eighteen PDCs. 
Table 3. Clinical data for the top three tumour types for the nineteen PDCs that are released by both cathepsins and change in $\mathrm{pH}$.

\begin{tabular}{|c|c|c|c|c|c|c|c|c|}
\hline \multirow[b]{2}{*}{ Tumour Type } & \multirow{2}{*}{$\begin{array}{l}\text { No. of Patients per } \\
\text { Tumour Total } \\
\text { [Ph I/Ph II/Ph III] }\end{array}$} & \multicolumn{6}{|c|}{ Clinical Responses ${ }^{\text {b }}$ Total $(\mathbf{P h}$ I/Ph II/Ph III) } & \multirow{2}{*}{$\begin{array}{c}\text { Tumour Response } \\
\text { Rate }^{\mathrm{c}}(\%) \text { Total } \\
{[\mathrm{Ph} \mathrm{I} / \mathrm{Ph} \text { II/Ph III] }}\end{array}$} \\
\hline & & $\begin{array}{c}\text { No. of } \\
\text { SD }\end{array}$ & $\begin{array}{c}\text { No. of } \\
\text { PR }\end{array}$ & $\begin{array}{c}\text { No. of } \\
\text { MR }\end{array}$ & $\begin{array}{c}\text { No. of } \\
\text { CR }\end{array}$ & $\begin{array}{c}\text { No. of } \\
\text { OS }\end{array}$ & $\begin{array}{c}\text { No. of } \\
\text { NR }\end{array}$ & \\
\hline \multicolumn{9}{|c|}{ HPMA copolymer-doxorubicin (PK1; FCE28068) $[4,20]$} \\
\hline Breast & $20[3 / 17(14) * /-]$ & $5[-/ 5 /-]$ & $3[-/ 3 /-]$ & $1[1 /-/-]$ & - & - & $8[2 / 6]$ & $53[33 / 57 /-]$ \\
\hline Colon and/or rectum & $24[8 / 16 /-]$ & - & - & $1[1 /-/-]$ & - & - & $23[7 / 16 /-]$ & $4[4 /-/-]$ \\
\hline \multicolumn{9}{|c|}{ HPMA copolymer-doxorubicin-galactosamine (PK2; FCE28069) [21] } \\
\hline Colon and/or rectum & $6[6 /-/-]$ & - & - & - & - & - & $6[6 /-/-]$ & 0 \\
\hline \multicolumn{9}{|c|}{ Carboxymethyldextran-exatecan; DE-310 [22] } \\
\hline Adenocarcinoma (Unknown primary) & $2[2 /-/-]$ & $1[1 /-/-]$ & - & - & $1[1 /-/-]$ & - & 0 & $100[100 /-/-]$ \\
\hline Pancreas & $3[3 /-/-]$ & $2[2 /-/-]$ & $1[1 /-/-]$ & - & - & - & 0 & $100[100 /-/-]$ \\
\hline Urinary & $1[1 /-/-]$ & $1[1 /-/-]$ & - & - & - & - & 0 & $100[100 /-/-]$ \\
\hline \multicolumn{9}{|c|}{ Delimotecan; MEN 4901/T-0128 [23] } \\
\hline \multicolumn{9}{|c|}{ Poly-L-glutamic acid-camptothecin; PGA-CPT; CT-2106 [24] } \\
\hline Breast & $4[4 /-/-]$ & $1[1 /-/-]$ & - & - & - & - & $3[3 /-/-]$ & $25[25 /-/-]$ \\
\hline Skin & $14[14 /-/-]$ & $2[2 /-/-]$ & - & - & - & - & $12[12 /-/-]$ & $14[14 /-/-]$ \\
\hline Bone & $1[1 /-/-]$ & - & - & - & - & - & $1[1 /-/-]$ & 0 \\
\hline \multicolumn{9}{|c|}{ Poly-L-glutamic acid-paclitaxel; PGA-PTX; CT2103; XYOTAX; OPAXIO ${ }^{\circledR}[5,6,19,24-33]$} \\
\hline Breast & $18[-/ 18 /-]$ & $2[-/ 2 /-]$ & $4[-/ 4 /-]$ & $4[-/ 4 /-]$ & - & - & $8[-/ 8 /-]$ & $56[-/ 56 /-]$ \\
\hline Ovary & $99[-/ 99 /-]$ & $32[-/ 32 /-]$ & $10[-/ 10 /-]$ & - & - & - & $57[-/ 57 /-]$ & $42[-/ 42 /-]$ \\
\hline Mesothelioma & $3[3 /-/-]$ & - & - & $1[1 /-/-]$ & - & - & $2[2 /-/-]$ & $33[33 /-/-]$ \\
\hline
\end{tabular}


Table 3. Cont.

\begin{tabular}{|c|c|c|c|c|c|c|c|c|}
\hline \multirow[b]{2}{*}{ Tumour Type } & \multirow{2}{*}{$\begin{array}{l}\text { No. of Patients per } \\
\text { Tumour Total } \\
\text { [Ph I/Ph II/Ph III] }\end{array}$} & \multicolumn{6}{|c|}{ Clinical Responses ${ }^{\mathrm{b}}$ Total $(\mathbf{P h} \mathrm{I} / \mathbf{P h}$ II/Ph III) } & \multirow{2}{*}{$\begin{array}{c}\text { Tumour Response } \\
\text { Rate }^{\mathrm{c}}(\%) \text { Total } \\
{[\mathrm{Ph} \mathrm{I} / \mathrm{Ph} \text { II/Ph III] }}\end{array}$} \\
\hline & & $\begin{array}{c}\text { No. of } \\
\text { SD }\end{array}$ & $\begin{array}{c}\text { No. of } \\
\text { PR } \\
\end{array}$ & $\begin{array}{c}\text { No. of } \\
\text { MR }\end{array}$ & $\begin{array}{c}\text { No. of } \\
\text { CR }\end{array}$ & $\begin{array}{c}\text { No. of } \\
\text { OS }\end{array}$ & $\begin{array}{c}\text { No. of } \\
\text { NR }\end{array}$ & \\
\hline \multicolumn{9}{|c|}{ HPMA copolymer-carboplatin; HPMA-carboplatin; AP5280 [35] } \\
\hline Ovary & $2[2 /-/-]$ & $1[1 /-/-]$ & - & - & - & - & $1[1 /-/-]$ & $50[50 /-/-]$ \\
\hline Colon and/or rectum & $12[12 /-/-]$ & $2[2 /-/-]$ & - & - & - & - & $10[10 /-/-]$ & $17[17 /-/-]$ \\
\hline \multicolumn{9}{|c|}{ HPMA copolymer-platinate; HPMA-Pt; AP5346 [36] } \\
\hline Oesophagus, stomach and intestine & $1[1 /-/-]$ & $1[1 /-/-]$ & - & - & - & - & 0 & $100[100 /-/-]$ \\
\hline Skin & $5[5 /-/-]$ & $1[1 /-/-]$ & $1[1 /-/-]$ & - & - & - & $3[3 /-/-]$ & $40[40 /-/-]$ \\
\hline \multicolumn{9}{|c|}{ Polyethylene-camptothecin; PEG-CPT; EZN246; Pegmaotecan; Prothecan ${ }^{\mathrm{TM}}[41-43]$} \\
\hline Bone & $1[1 /-/-]$ & - & - & $1[1 /-/-]$ & - & - & $0[0 /-/-]$ & $100[100 /-/-]$ \\
\hline Oesophagus, stomach and intestine & $42[7 / 35 /-]$ & $14[-/ 14 /-]$ & $5[-/ 5 /-]$ & $3[2 / 1 /-]$ & - & - & $20[5 / 15 /-]$ & $52[29 / 57 /-]$ \\
\hline Unknown primary & $5[5 /-/-]$ & - & - & $1[1 /-/-]$ & & & $4[4 /-/-]$ & $20[20 /-/-]$ \\
\hline Breast & $3[3 /-/-]$ & $2[2 /-/-]$ & - & - & - & & $1[1 /-/-]$ & $67[67 /-/-]$ \\
\hline \multicolumn{9}{|c|}{ PHF-CPT; MER-1001; XMT-1001 [52] } \\
\hline Skin & $2[2 /-/-]$ & $1[1 /-/-]$ & - & - & - & - & $1[1 /-/-]$ & $50[50 /-/-]$ \\
\hline Lung & $7[7 /-/-]$ & $3[3 /-/-]$ & - & - & - & - & $4[4 /-/-]$ & $43[43 /-/-]$ \\
\hline Solid tumours (Unspecified) & $8[8 /-/-]$ & $3[3 /-/-]$ & - & - & - & - & $5[5 /-/-]$ & $38[38 /-/-]$ \\
\hline \multicolumn{9}{|c|}{ Cyclodextrin-camptothecin; CRLX101; IT-101 [53] } \\
\hline Lung & $27[27 /-/-]$ & $16[16 /-/-]$ & - & - & - & - & $11[11 /-/-]$ & $59[59 /-/-]$ \\
\hline Solid tumours * & $35[35 /-/-]$ & $28[28 /-/-]$ & - & - & - & - & $7[7 /-/-]$ & $80[80 /-/-]$ \\
\hline
\end{tabular}


Table 3. Cont

\begin{tabular}{|c|c|c|c|c|c|c|c|c|}
\hline \multirow[b]{2}{*}{ Tumour Type } & \multirow{2}{*}{$\begin{array}{l}\text { No. of Patients per } \\
\text { Tumour Total } \\
\text { [Ph I/Ph II/Ph III] }\end{array}$} & \multicolumn{6}{|c|}{ Clinical Responses ${ }^{\mathrm{b}}$ Total $(\mathbf{P h} \mathrm{I} / \mathbf{P h}$ II/Ph III) } & \multirow{2}{*}{$\begin{array}{c}\text { Tumour Response } \\
\text { Rate }^{\mathrm{c}}(\%) \text { Total } \\
{[\mathrm{Ph} \mathrm{I} / \mathrm{Ph} \text { II/Ph III] }}\end{array}$} \\
\hline & & $\begin{array}{c}\text { No. of } \\
\text { SD }\end{array}$ & $\begin{array}{c}\text { No. of } \\
\text { PR }\end{array}$ & $\begin{array}{c}\text { No. of } \\
\text { MR }\end{array}$ & $\begin{array}{c}\text { No. of } \\
\text { CR }\end{array}$ & $\begin{array}{c}\text { No. of } \\
\text { OS }\end{array}$ & $\begin{array}{c}\text { No. of } \\
\text { NR }\end{array}$ & \\
\hline \multicolumn{9}{|c|}{ HA-paclitaxel (ONCOFID-PTM) [54] } \\
\hline \multicolumn{9}{|c|}{ Oxidized dextran-Dox; OXD-DOX (AD-70) [55] } \\
\hline Colon and/or rectum & $6[6 /-/-]$ & $1[1 /-/-]$ & - & - & - & - & $5[5 /-/-]$ & $17[17 /-/-]$ \\
\hline Oesophagus, stomach and intestine & $2[2 /-/-]$ & - & - & - & - & - & $2[2 /-/-]$ & 0 \\
\hline \multicolumn{9}{|c|}{ HPMA copolymer-paclitaxel; HPMA-PTX; PNU166945 [37] } \\
\hline Solid tumours ${ }^{1}$ & $12[12 /-/-]$ & $2[2 /-/-]$ & $1[1 /-/-]$ & - & - & - & $9[9 /-/-]$ & $25[25 /-/-]$ \\
\hline \multicolumn{9}{|c|}{ HPMA copolymer-camptothecin; HPMA-CPT; PNU166148 [38-40] } \\
\hline Solid tumours $^{2}$ & $40[40 /-/-]$ & $5[5 /-/-]$ & - & $1[1 /-/-]$ & - & - & $34[34 /-/-]$ & $15[15 /-/-]$ \\
\hline \multicolumn{9}{|c|}{ Polyethylene glycol-paclitaxel; PEG-PTX [44] } \\
\hline Solid tumours ${ }^{3}$ & 13 & & & NA & & & $\mathrm{NC}$ & $\mathrm{NC}$ \\
\hline NA & 17 & NA & NA & NA & NA & NA & $\mathrm{NC}$ & $\mathrm{NC}$ \\
\hline
\end{tabular}

Notes: ${ }^{\text {a }}$ Indicates total number of patients considered for the clinical evaluation; ${ }^{\mathrm{b}}$ Clinical responses includes the total of SD, Stable disease; PR, Partial response; MR, Minor response; CR, Complete response; OS, Overall survival; NR, No response; ${ }^{\mathrm{c}}$ Tumour response rate (\%) is the added responses $(\mathrm{SD}+\mathrm{PR}+\mathrm{MR}+\mathrm{CR}+\mathrm{OS}) \mathrm{per}$ tumour type. NA, Not available, NC, Not calculated. "Indicates number of patients evaluated for the tumour responses. The term "Solid tumours" has been mentioned wherever the clinical responses per tumour type have not been reported in the respective study. ${ }^{1}$ Solid tumours includes (number of patients is denoted in the brackets for those that are available in the study)-Ovary (4); Breast (2); Colon and/or rectum (2); Lung (1) and others (3); ${ }^{2}$ Solid tumours includes-Colon and/or rectum (18); Ovary (2); Oesophagus, stomach and intestine (4); Unknown primary (4); Head/Neck and brain (2); Lung (6); Kidney (3); Adrenal (1); Cervix (1); Bone (1); Mesothelioma (1); Prostate (1) and Sarcoma (3); ${ }^{3}$ Solid tumours includes-Colon and/or rectum (3); Breast (2); Neuroendocrine (2); Lung (1); Prostate (1) and Others (4); ${ }^{4}$ Solid tumours includes-Ovary; Breast; Adrenal; Oesophagus, stomach and intestine; Lymphoma; Lung; Cervix; Head/Neck and brain; Urinary and Breast. 
Finally, summary graphics assembling the percentage responses per tumour type for all conjugates were compiled (Figure 3 and Table 4). Figure 3 and Table 4 shows the percentage responses observed for cathepsin-activated conjugates. Breast, ovary and lung cancer were the cancer types in which the highest response rates were observed $(>30 \%)$. However, the responses observed for the various conjugates in each tumour type were variable, for example, the HPMA copolymer-oxaliplatin conjugate (AP5346/ProLindac) showed no responses in breast cancer while the HPMA copolymer-doxorubicin conjugate (PK1) showed 53\% response in that tumour. This variability might be due to the fact that the latter relies solely on cathepsins for drug release, and hence has a more specific activation than the former, for which both cathepsins and acid hydrolysis play a role in the release of oxaliplatin. This finding however can also be affected to some extent by the nature of the therapeutic agent.

Figure 3. Graphical representation of the tumuor response rates for PDCs (release mediated only by cathepsin).

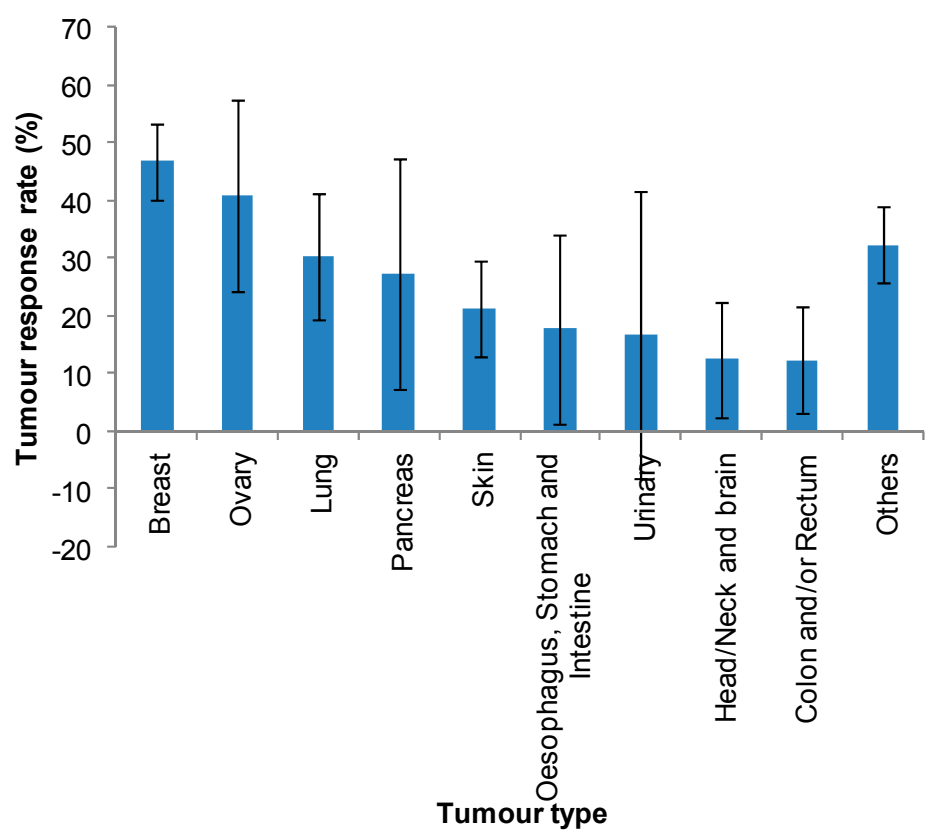

Table 4. Tumour response rates for PDCs (release mediated only by cathepsin).

\begin{tabular}{|c|c|c|c|c|c|c|c|c|c|}
\hline \multirow[b]{2}{*}{ PDC } & \multicolumn{9}{|c|}{ Tumour response rate $(\%)$} \\
\hline & Breast & Ovary & Lung & Pancreas & Skin & $\begin{array}{l}\text { Oesophagus, } \\
\text { Stomach and } \\
\text { Intestine }\end{array}$ & Urinary & $\begin{array}{c}\text { Head/Neck } \\
\text { and Brain }\end{array}$ & $\begin{array}{c}\text { Colon } \\
\text { and/or } \\
\text { Rectum }\end{array}$ \\
\hline PK1 & 53 & 0 & 56 & 0 & - & 0 & 0 & 0 & 4 \\
\hline PK2 & - & - & - & - & - & - & - & - & 0 \\
\hline DE-310 & - & 100 & 67 & 100 & 33 & 0 & 100 & - & 67 \\
\hline MEN4901 & - & - & 0 & - & 0 & 0 & 0 & 50 & 14 \\
\hline CT-2106 & 25 & - & 0 & 0 & 14 & - & - & - & 0 \\
\hline CT-2103 & 56 & 42 & 30 & - & - & 21 & - & 0 & 0 \\
\hline AP5280 & - & 50 & 50 & 0 & 0 & 0 & - & 0 & 16 \\
\hline AP5346 & 0 & 25 & 0 & 0 & 40 & 100 & 0 & 0 & - \\
\hline $\begin{array}{c}\text { Normalised } \\
\text { Average * }\end{array}$ & 47 & 41 & 30 & 27 & 21 & 18 & 17 & 13 & 12 \\
\hline SD & 26 & 37 & 29 & 45 & 19 & 40 & 50 & 22 & 24 \\
\hline SE & 13 & 17 & 11 & 20 & 8 & 16 & 25 & 10 & 9 \\
\hline
\end{tabular}

Notes: * Averages were normalised to take into account of the number of patients evaluated for each conjugated, see experimental section; "-" indicates that the conjugate was not evaluated against the particular tumour type. 
Figure 4 and Table 5 show the result for all conjugates, independent of their activation mechanism. The results are similar to that observed for cathepsin-activated PDCs, with breast, ovary and lung cancer still achieving $>30 \%$ responses. However, urinary cancer and cancers of the oesophagus, stomach and intestines showed a high response as well (48\% and 34\%, respectively).

Figure 4. Graphical representation of the tumuor response rates for PDCs (release mediated both by cathepsin and $\mathrm{pH}$ ).

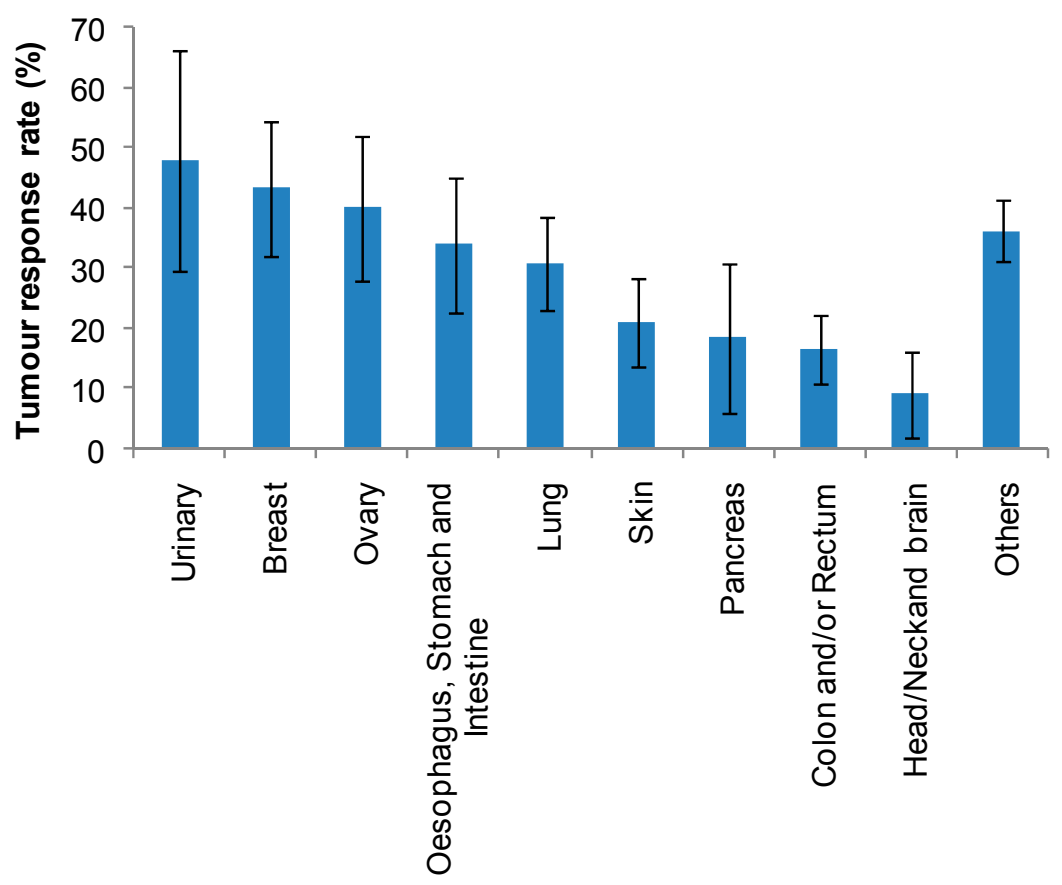

Tumour type

\subsection{Cathepsin Levels in Different Tumour Types}

Having assessed which tumour types showed the highest responses to PDCs, we investigated which tumour types had been reported to express the highest levels of cathepsins.

Cathepsins are lysosomal cysteine proteases involved in the bulk degradation of intracellular and endocytosed proteins. Cathepsin B is a large lysosmal protease that is generally over expressed in tumour tissues and plays a very important role in the release and activation of PDCs. Several studies have indicated that its co-existing isoenzymes such as cathepsin D, L, H, S and X are also overexpressed in tumour tissues and are thought to play a role in proteolysis [60-63]. Some studies have been carried out to elucidate precisely which isoenzyme contributes to drug release. For example, extensive studies carried out in the 80s have identified cathepsin B as the primary enzyme responsible for doxorubicin release from the HPMA copolymer-Dox conjugate, when a Gly-Phe-Leu-Gly (GFLG) linker was used. However, the release mechanism for other conjugates has not been investigated so extensively. Also, it is known that various isoenzymes can contribute to drug release from peptidyl linkers, for example, both cathepsin L and cathepsin B were found to contribute to the release of daunorubicin when GPLG and GPPL linkers were used [64]. Similarly, both cathepsin B and cathepsin H contributed to the release of 5-FU, albeit to a different extent [65]. The level of expression of these cathepsins in tumour 
tissues (especially cathepsin B) is very crucial for the selective release of the drug from the PDC within the tumour environment (Table 1). Also, several studies have indicated that cathepsin expression in tumours varies greatly [63] which is affected by various parameters including gender, age and hormone levels $[14,18]$. Therefore, to determine if there is a correlation between the level of cathepsin expression in a tumour type, and the clinical response to cathepsin-activated PDCs, data on cathepsin levels is presented for clinical as well as for in vivo and in vitro samples of different tumour types to obtain reliable results (Table 6). The information on tumour grades and other parameters that are related to the cathepsin's expression were limited in the original studies, hence these details have not been considered in our present study.

Table 5. Tumour response rates for PDCs (release mediated both by cathepsin and $\mathrm{pH}$ ).

\begin{tabular}{|c|c|c|c|c|c|c|c|c|c|}
\hline \multirow{2}{*}{$\begin{array}{r}\text { Tumour } \\
\text { PDC }\end{array}$} & \multicolumn{9}{|c|}{ Tumour response rate (\%) } \\
\hline & Urinary & Breast & Ovary & $\begin{array}{c}\text { Oesophagus, } \\
\text { Stomach and } \\
\text { Intestine }\end{array}$ & Lung & Skin & Pancreas & $\begin{array}{c}\text { Colon } \\
\text { and/or } \\
\text { Rectum }\end{array}$ & $\begin{array}{c}\text { Head/ } \\
\text { Neck and } \\
\text { Brain }\end{array}$ \\
\hline PK1 & 0 & 53 & 0 & 0 & 56 & - & 0 & 4 & 0 \\
\hline PK2 & - & - & - & - & - & - & - & 0 & - \\
\hline DE-310 & 100 & - & 100 & 0 & 67 & 33 & 100 & 67 & - \\
\hline MEN4901 & 0 & - & - & 0 & 0 & 0 & - & 14 & 50 \\
\hline CT-2106 & - & 25 & - & - & 0 & 14 & 0 & 0 & - \\
\hline CT-2103 & - & 56 & 42 & 21 & 30 & - & - & 0 & 0 \\
\hline AP5280 & - & - & 50 & 0 & 50 & 0 & 0 & 16 & 0 \\
\hline AP5346 & 0 & 0 & 25 & 100 & 0 & 40 & 0 & - & 0 \\
\hline \multicolumn{10}{|l|}{ PNU166945 a } \\
\hline \multicolumn{10}{|l|}{ PNU166148 a } \\
\hline EZN246 & - & 0 & 0 & 47 & 14 & 0 & 0 & 0 & 0 \\
\hline PEG-PTX & & & & & $\mathrm{NC}$ & & & & \\
\hline EZN2208 & 100 & 67 & 0 & - & 50 & - & 33 & 20 & - \\
\hline NKTR-102 & - & - & - & 1 & - & - & - & - & - \\
\hline NKTR-105 & & & & & $\mathrm{NC}$ & & & & \\
\hline XMT-1001 & - & 0 & 33 & 33 & 43 & 50 & 11 & 18 & - \\
\hline IT-101 & - & - & - & - & 59 & - & - & - & - \\
\hline ONCOFID-P & 60 & - & - & - & - & - & - & - & - \\
\hline $\mathrm{AD}-70$ & 0 & - & - & 0 & 0 & 0 & - & 17 & 0 \\
\hline $\begin{array}{c}\text { Normalised } \\
\text { average * }\end{array}$ & 48 & 43 & 40 & 34 & 31 & 21 & 18 & 16 & 9 \\
\hline SD & 48 & 30 & 34 & 36 & 26 & 21 & 35 & 20 & 19 \\
\hline SE & 18 & 11 & 12 & 13 & 8 & 7 & 12 & 6 & 7 \\
\hline
\end{tabular}

Notes: * Averages were normalised to take into account of the number of patients evaluated for each conjugated, see experimental section; “-” indicates that the conjugate was not evaluated against the particular tumour type; ${ }^{a}$ The clinical responses for this conjugate are considered under the tumour type "others" as the responses per specific tumour type has not been mentioned in the original references [36-39]. NC: Not considered. 
Table 6. Cathepsin levels found in clinical and preclinical sample of different tumour types (clinical studies highlighted in grey).

\begin{tabular}{|c|c|c|c|c|c|}
\hline Tumour Type & $\begin{array}{c}\text { Type of } \\
\text { Cathepsin } \\
(\text { CAT }) \\
\end{array}$ & $\begin{array}{c}\text { Clinical }(\mathbf{C}) / \\
\text { Pre-Clinical } \\
(\mathbf{P C}) / \text { In vitro }(\mathbf{I V}) \\
\end{array}$ & $\begin{array}{l}\text { Sample } \\
\text { Size }(n)\end{array}$ & Cathepsin Content & Reference \\
\hline \multirow{8}{*}{ Lung } & CAT B & $\mathrm{C}$ & 105 & $10.65 \mathrm{ng} / \mathrm{mL}$ & [66] \\
\hline & CAT B & $\mathrm{C}$ & 17 & $448 \mathrm{ng} / \mathrm{mg}$ of protein & [67] \\
\hline & CAT B & $\mathrm{PC}$ & 159 & High * & [68] \\
\hline & CAT D & $\mathrm{C}$ & 17 & $1304 \mathrm{ng} / \mathrm{mg}$ of protein & [67] \\
\hline & CAT S & $\mathrm{C}$ & 60 & $4.2 \pm 0.22 \mathrm{ng} / \mathrm{mg}$ of protein & [69] \\
\hline & CAT H & $\mathrm{C}$ & 123 & $172 \pm 86 \mathrm{ng} / \mathrm{mg}$ of protein & [70] \\
\hline & CAT L & $\mathrm{C}$ & 105 & $26.16 \mathrm{ng} / \mathrm{mL}$ & [66] \\
\hline & CAT L & $\mathrm{C}$ & 17 & $3835 \mathrm{ng} / \mathrm{mg}$ of protein & [68] \\
\hline \multirow{11}{*}{$\begin{array}{l}\text { Head/Neck } \\
\text { and brain }\end{array}$} & CAT B & $\mathrm{C}$ & 84 & High * & [71] \\
\hline & CAT B & $\mathrm{C}$ & 47 & High * & [72] \\
\hline & CAT B & $\mathrm{C}$ & 32 & High * & [73] \\
\hline & CAT B & $\mathrm{PC}$ & NA & High * & [74] \\
\hline & CAT B & $\mathrm{PC}$ & NA & High * & [75] \\
\hline & CAT B & PC & 11 & High * & [76] \\
\hline & CAT B & PC & NA & High * & [77] \\
\hline & CAT D & $\mathrm{PC}$ & 7 & $1300 \mathrm{ng} / \mathrm{mg}$ of protein & [78] \\
\hline & CAT S & $\mathrm{PC}$ & 11 & Low * & [76] \\
\hline & CAT H & $\mathrm{PC}$ & 7 & $1500 \mathrm{ng} / \mathrm{mg}$ of protein & [79] \\
\hline & CAT L & $\mathrm{PC}$ & 11 & Low * & [76] \\
\hline \multirow{4}{*}{$\begin{array}{l}\text { Oesophagus, stomach } \\
\text { and intestine }\end{array}$} & CAT B & $\mathrm{C}$ & 25 & $325.9 \mathrm{ng} / \mathrm{mg}$ of protein & {$[80]$} \\
\hline & CAT B & $\mathrm{C}$ & 175 & $10.83 \pm 1.8 \mathrm{ng} / \mathrm{mL}$ & [81] \\
\hline & CAT B & $\mathrm{PC}$ & NA & Low * & [67] \\
\hline & CAT L & $\mathrm{C}$ & 25 & $43.6 \mathrm{ng} / \mathrm{mg}$ of protein & {$[80]$} \\
\hline \multirow{3}{*}{ Colon and/or rectum } & CAT B & $\mathrm{C}$ & 72 & $13.38 \mathrm{ng} / \mathrm{mL}$ & [81] \\
\hline & CAT B & $\mathrm{C}$ & 108 & $168 \pm 86 \mathrm{ng} / \mathrm{mg}$ of protein & [82] \\
\hline & CAT B & $\mathrm{C}$ & 60 & $253.5 \mathrm{ng} / \mathrm{mg}$ of protein & [82] \\
\hline \multirow{6}{*}{ Colon and/or rectum } & CAT B & $\mathrm{C}$ & 74 & $55 \pm 5 \mathrm{hg} / \mathrm{mg}$ of protein & [83] \\
\hline & CAT B & PC & 40 & High * & [84] \\
\hline & CAT X & $\mathrm{C}$ & 77 & $17.4 \mathrm{ng} / \mathrm{mL}$ & {$[85]$} \\
\hline & CAT H & $\mathrm{C}$ & 74 & $7 \pm 1 \mathrm{ng} / \mathrm{mg}$ of protein & [83] \\
\hline & CAT L & $\mathrm{C}$ & 74 & $50 \pm 10 \mathrm{ng} / \mathrm{mg}$ of protein & [83] \\
\hline & CAT L & $\mathrm{C}$ & 60 & $274 \mathrm{ng} / \mathrm{mg}$ of protein & [82] \\
\hline \multirow{6}{*}{ Breast } & CAT B & $\mathrm{C}$ & 30 & $74 \mathrm{ng} / \mathrm{mg}$ of protein & [86] \\
\hline & CAT B & PC (DU4475) & 4 & High * & [86] \\
\hline & CAT B & IV (BT20) & NA & Low * & [87] \\
\hline & CAT D & $\mathrm{C}$ & 57 & High * & [88] \\
\hline & CAT X & IV (MCF-7) & NA & $2.5 \mathrm{ng} / \mathrm{mL}$ & [89] \\
\hline & CAT X & IV (MDA-MB-231) & NA & $37 \mathrm{ng} / \mathrm{mL}$ & [89] \\
\hline
\end{tabular}


Table 6. Cont.

\begin{tabular}{cccccc}
\hline Tumour Type & $\begin{array}{c}\text { Type of } \\
\text { Cathepsin } \\
(\text { CAT })\end{array}$ & $\begin{array}{c}\text { Clinical (C)/ } \\
\text { Pre-Clinical } \\
(\text { PC) } / \text { In vitro }(\mathbf{I V})\end{array}$ & $\begin{array}{c}\text { Sample } \\
\text { Size (n) }\end{array}$ & Cathepsin Content & Reference \\
\hline Ovary & CAT L & C & 318 & $16.1 \pm 5.1 \mathrm{ng} / \mathrm{mL}$ & {$[90]$} \\
Pancreas & CAT B & PC & NA & High * & {$[91]$} \\
Urinary & CAT B & PC & 7 & High * & {$[67]$} \\
\hline Others & & & & & \\
\hline Liver & CAT B & C & 28 & $13.46 \mathrm{ng} / \mathrm{mL}$ & {$[81]$} \\
\hline
\end{tabular}

Notes: * The cathepsin levels are expressed as high and low (rather than a specific value) for those entries in which definite quantitative values were not available in the original study; NA, Not applicable; " $n$ " = number of human/animal subjects.

Two tumours, lung and breast, which have shown the highest percentage response clinically to PDCs activated by cathepsins, also showed a generally high content of this class of enzyme (in some studies, as high as $3835 \mathrm{ng} / \mathrm{mg}$ for lung cancer). This correlation is as expected, as the presence of a trigger is essential for the activation of a prodrug, but has not been widely reported from analysis of experimental data. It should also be noted that the content of cathepsins reported in various studies concerning the same tumour type were highly variable. This finding suggests that heterogeneity might be also present in the tumour samples of the patients that have undergone treatment with PDCs and this could potentially explain why only a fraction of the patients enrolled in the clinical studies responded to the treatment $[92,93]$. Differences in the content of cathepsins are particularly marked for breast cancer. For example, the content of cathepsin B was reported to be "high" in the study from Bremer et al. [86] but "low" from that of Hulkower et al. [87]. It is also key to highlight that, as mentioned previously, cathepsins level have been found to be affected by oestrogen levels and therefore an additional element of variability is added depending on whether the sample is taken from a post-menopausal or pre-menopausal woman $[5,18]$.

\subsection{Magnitude of the EPR Effect in Different Tumour Types}

A second, but at least equally important, factor for activity of PDCs is the extent of the EPR effect in a tumour. To establish if there was a correlation between the magnitude of the EPR effect and the tumour's response to PDCs, data on drug accumulation of different drug delivery technologies such as PDCs and liposomes in clinical tumour samples as well as in preclinical samples were collected as summarised in Table 7. Although this comparison holds a limitation with respect to the heterogeneity of systems (different nanoconstructs and different phases of clinical research) and heterogeneous tumour types, pooling the results from such heterogeneous data was necessary due to the limited clinical studies on EPR effect with PDCs. Different methodologies have been used in different studies to evaluate the extent of passive accumulation in the tumour both qualitatively and quantitatively. For example, in some studies analogues of conjugates containing radioisotopes were used with imaging techniques where the results were expressed qualitatively (i.e., expressed as whether drug accumulation was or was not observed) and quantitatively (expressed as $\% \mathrm{ID} / \mathrm{Kg}$ of drug uptake in tumour). Similarly with the staining technique using Evan's blue dye the results were expressed both qualitatively 
and quantitatively (expressed as \% dose/g/tumour). A few studies involved the comparison between the free drug accumulation and the nano particle accumulation in which case the results were expressed in terms of degree of their accumulation. Some studies have indicated that the extent of the EPR effect is also dependent on the tumour sizes $[3,13,94]$ but due to the lack of information on the tumour sizes in most of the studies, this factor was not considered in our evaluation.

EPR-mediated accumulation was generally observed in all the tumour types where the highest percentage responses were reported (namely breast, lung and ovary). Studies on liposomal drug accumulation have shown poor EPR effects in liver and pancreatic tumours [95,96]. Colorectal cancer was another tumour type where poor EPR effect has been reported in some studies $([11,20]$ and Table 7). This observation is probably mainly due to the fact that large tumours in liver, pancreas and prostate possess hypovascular properties with low drug accumulation potential. However, it should be remembered that the smaller tumours possess high vascular density and can exhibit profound EPR effect [97].

This observation also correlates with a recent study on validation of the tumour models for EPR activity, where high drug accumulation has been reported for both large and small lung tumours, and a low drug accumulation has been reported for the large breast tumours [13]. Disparities observed across the various studies are might be due to the heterogeneity within and between the tumour types (size and histological differences) and the diversity of the nanopharmaceutical characteristics [14].

Table 7. Extent of passive accumulation of macromolecular system in different tumour types in both clinical and pre-clinical samples, clinical studies highlighted in grey.

\begin{tabular}{|c|c|c|c|c|c|}
\hline Tumour Type & $\begin{array}{c}\text { Clinical }(\mathbf{C}) / \\
\text { Pre-Clinical }(\mathbf{P C})\end{array}$ & $\begin{array}{l}\text { Sample } \\
\text { Size }(n)\end{array}$ & $\begin{array}{c}\text { Macromolecule } \\
\text { System Used }\end{array}$ & Remarks & Reference \\
\hline \multirow{9}{*}{ Breast } & $\mathrm{C}$ & 2 & PDC & $\begin{array}{c}1.8 \%-5.9 \% \text { dose of PDC } \\
\text { uptake in tumour }\end{array}$ & {$[20]$} \\
\hline & $\mathrm{C}$ & 5 & Liposome & $\begin{array}{c}5.3 \% \pm 2.6 \% \mathrm{ID} / \mathrm{Kg} \text { of drug } \\
\text { uptake in tumour }\end{array}$ & [97] \\
\hline & $\mathrm{C}$ & 6 & Liposome & $\begin{array}{l}\text { 4-16 fold higher drug } \\
\text { accumulation in tumour than } \\
\text { the free drug }\end{array}$ & [98] \\
\hline & $\begin{array}{c}\text { PC (MX-1, } \\
\text { Human xenograft) }\end{array}$ & 10 & Protein-conjugate & $\begin{array}{l}33 \% \text { higher drug accumulation } \\
\text { in tumour than the free drug }\end{array}$ & [99] \\
\hline & $\begin{array}{l}\text { PC (MAXF 449, } \\
\text { Human xenograft) }\end{array}$ & NA & PDC & $\begin{array}{c}1.0 \%-0.1 \% \text { dose } / \mathrm{g} / \text { tumour } \\
\text { drug accumulation }\end{array}$ & {$[13]$} \\
\hline & PC (Mouse) & NA & PDC & $\begin{array}{l}5.29 \% \text { dose } / g \text { for HMW } \\
3.18 \% \text { dose } / g \text { for LMW }\end{array}$ & {$[100]$} \\
\hline & PC (MX-1) & NA & PDC & $\begin{array}{l}207 \text { fold higher tumour } \\
\text { exposure than the free drug } \\
\text { (SN-38) }\end{array}$ & {$[101]$} \\
\hline & $\begin{array}{c}\text { PC } \\
\text { (Walker 256, Rat) }\end{array}$ & NA & Protein-conjugate & $\begin{array}{c}7 \text { fold higher drug } \\
\text { accumulation in tumour than } \\
\text { the free drug }\end{array}$ & [102] \\
\hline & PC (Mouse) & NA & Nanoparticle & $\begin{array}{l}\text { Drug accumulation observed } \\
\text { in tumour } *\end{array}$ & [103] \\
\hline
\end{tabular}


Table 7. Cont.

\begin{tabular}{|c|c|c|c|c|c|}
\hline Tumour Type & $\begin{array}{c}\text { Clinical (C)/ } \\
\text { Pre-Clinical (PC) }\end{array}$ & $\begin{array}{l}\text { Sample } \\
\text { Size }(n)\end{array}$ & $\begin{array}{c}\text { Macromolecule } \\
\text { System Used } \\
\end{array}$ & Remarks & Reference \\
\hline \multirow[b]{2}{*}{ Pancreas } & $\mathrm{C}$ & NA & Liposomes & $\begin{array}{l}\text { Low drug accumulation } \\
\text { observed in tumour * }\end{array}$ & {$[95]$} \\
\hline & PC (Mouse) & 40 & Micelle & $\begin{array}{c}3 \text { fold higher drug } \\
\text { accumulation in tumour than } \\
\text { the free drug }\end{array}$ & {$[104]$} \\
\hline \multirow{11}{*}{ Lung } & $\mathrm{C}$ & 6 & PDC & $\begin{array}{l}\text { No drug accumulation } \\
\text { observed in tumour * }\end{array}$ & [20] \\
\hline & $\mathrm{C}$ & 4 & Liposome & $\begin{array}{c}18.3 \% \pm 5.7 \% \mathrm{ID} / \mathrm{Kg} \text { of drug } \\
\text { uptake in tumour }{ }^{\#}\end{array}$ & [97] \\
\hline & $\mathrm{C}$ & 3 & Liposome & $\begin{array}{l}4-16 \text { fold higher drug } \\
\text { accumulation in tumour than } \\
\text { the free drug }\end{array}$ & [98] \\
\hline & $\mathrm{C}$ & 15 & Liposome & $\begin{array}{l}\text { Higher drug accumulation } \\
\text { observed in tumour * }\end{array}$ & {$[105]$} \\
\hline & PC (Meta-7, Mouse) & NA & PDC & $\begin{array}{c}3.5 \%-4.7 \% \text { dose } / \mathrm{g} / \text { tumour } \\
\text { drug accumulation }\end{array}$ & [13] \\
\hline & $\begin{array}{c}\text { PC (COR L23, } \\
\text { Human xenograft) }\end{array}$ & NA & PDC & $\begin{array}{c}4.7 \%-12.2 \% \text { dose } / \mathrm{g} / \text { tumour } \\
\text { drug accumulation }\end{array}$ & {$[13]$} \\
\hline & PC (B16, Mouse) & NA & Liposomes & $10.6 \% \pm 0.2 \% \mathrm{ID} / \mathrm{g}$ of tumour & [106] \\
\hline & $\begin{array}{l}\text { PC (B16F10, } \\
\text { Mouse) }\end{array}$ & NA & PDC & $\begin{array}{c}8.82 \% \text { dose/g for HMW } 3.23 \% \\
\text { dose/g for LMW }\end{array}$ & {$[100]$} \\
\hline & PC (B16, Mouse) & NA & Micelle & $\begin{array}{l}2-3 \text { fold higher drug } \\
\text { accumulation in tumour than } \\
\text { the free drug }\end{array}$ & {$[107]$} \\
\hline & PC (B16, Mouse) & NA & PDC & $\begin{array}{c}6-12 \text { fold higher drug } \\
\text { accumulation in tumour than } \\
\text { the free drug }\end{array}$ & {$[28]$} \\
\hline & PC (B16, Mouse) & 3 & PDC & $\begin{array}{l}\text { Higher drug accumulation } \\
\text { observed in tumour * }\end{array}$ & {$[108]$} \\
\hline \multirow{3}{*}{ Lung } & PC (A431, Mouse) & NA & Protein-conjugate & $\begin{array}{c}24 \text { fold higher drug } \\
\text { accumulation in tumour than } \\
\text { the free drug }\end{array}$ & [109] \\
\hline & PC (B16, Mouse) & NA & PDC & $\begin{array}{c}\text { 30-63 fold higher drug } \\
\text { accumulation in tumour than } \\
\text { the free drug }\end{array}$ & [110] \\
\hline & PC (B16, Mouse) & NA & PDC & $\begin{array}{l}16.3 \text { fold higher drug } \\
\text { accumulation in tumour than } \\
\text { the free drug }\end{array}$ & [111] \\
\hline
\end{tabular}


Table 7. Cont.

\begin{tabular}{|c|c|c|c|c|c|}
\hline Tumour Type & $\begin{array}{c}\text { Clinical (C)/ } \\
\text { Pre-Clinical (PC) }\end{array}$ & $\begin{array}{l}\text { Sample } \\
\text { Size }(n)\end{array}$ & $\begin{array}{c}\text { Macromolecule } \\
\text { System Used }\end{array}$ & Remarks & Reference \\
\hline \multirow{6}{*}{ Ovary } & $\mathrm{C}$ & 3 & Liposome & $\begin{array}{l}4-16 \text { fold higher drug } \\
\text { accumulation in tumour than the } \\
\text { free drug }\end{array}$ & [98] \\
\hline & PC (Mouse) & NA & PDC & $\begin{array}{l}\text { Drug accumulation observed } \\
\text { in tumour * }\end{array}$ & [28] \\
\hline & $\begin{array}{l}\text { PC (Oca-1, } \\
\text { Mouse) }\end{array}$ & NA & PDC & $\begin{array}{c}5 \text { fold higher drug accumulation } \\
\text { in tumour } \\
\text { than the free drug }\end{array}$ & [112] \\
\hline & $\begin{array}{l}\text { PC (Oca-1, } \\
\text { Mouse) }\end{array}$ & NA & $\mathrm{PDC}$ & $\begin{array}{l}28-38 \text { times higher drug } \\
\text { accumulation in tumour than the } \\
\text { free drug }\end{array}$ & [113] \\
\hline & $\begin{array}{c}\text { PC (A2780, } \\
\text { Human xenograft) }\end{array}$ & NA & PDC & $\begin{array}{l}\text { Drug accumulation observed } \\
\text { in tumour * }\end{array}$ & [114] \\
\hline & $\begin{array}{l}\text { PC (OVCAR-3, } \\
\text { Human xenograft) }\end{array}$ & NA & $\mathrm{PDC}$ & $\begin{array}{l}45 \text { fold higher drug } \\
\text { accumulation in tumour } \\
\text { than the free drug }\end{array}$ & [115] \\
\hline \multirow{2}{*}{$\begin{array}{l}\text { Oesophageal, } \\
\text { stomach and } \\
\text { intestine }\end{array}$} & PC (Mouse) & NA & PDC & $\begin{array}{l}\text { Drug accumulation observed } \\
\text { in tumour * }\end{array}$ & [116] \\
\hline & $\begin{array}{c}\text { PC } \\
\text { (OCUM-2MLN, } \\
\text { Human xenograft) }\end{array}$ & NA & Micelle & $\begin{array}{l}\text { Drug accumulation observed } \\
\text { in tumour* }\end{array}$ & [117] \\
\hline \multirow{5}{*}{$\begin{array}{l}\text { Colon and/or } \\
\text { rectum }\end{array}$} & $\mathrm{C}$ & 5 & PDC & $\begin{array}{l}\text { No drug accumulation observed } \\
\text { in tumour * }\end{array}$ & [20] \\
\hline & $\mathrm{C}$ & 10 & PDC & $\begin{array}{l}64 \text { fold higher drug accumulation } \\
\text { in tumour than the free drug }\end{array}$ & [118] \\
\hline & $\begin{array}{l}\text { PC (HT29, Human } \\
\text { xenograft) }\end{array}$ & 4 & Liposome & $\begin{array}{l}1.7 \text { fold higher drug } \\
\text { accumulation for } 0.6 \mathrm{~mol} \% \\
\text { PEG-conjugate in tumour } \\
\text { than the free drug }\end{array}$ & [119] \\
\hline & $\begin{array}{c}\text { PC (C26 NL-17, } \\
\text { Mouse) }\end{array}$ & NA & Liposome & $\begin{array}{l}\text { Higher drug accumulation } \\
\text { observed in tumour * }\end{array}$ & [120] \\
\hline & PC (Mouse) & NA & Micelle & $\begin{array}{l}\text { Drug accumulation observed } \\
\text { in tumour * }\end{array}$ & [121] \\
\hline \multirow{6}{*}{$\begin{array}{l}\text { Colon and/or } \\
\text { rectum }\end{array}$} & $\begin{array}{c}\text { PC (LS174T, } \\
\text { Human xenograft) }\end{array}$ & NA & $\mathrm{PDC}$ & $\begin{array}{l}160 \text { fold higher drug } \\
\text { accumulation in tumour than the } \\
\text { free drug }\end{array}$ & [122] \\
\hline & $\begin{array}{c}\text { PC (LS174T, } \\
\text { Human xenograft) }\end{array}$ & NA & Liposomes & $\begin{array}{c}6.3 \% \pm 2.9 \% \mathrm{ID} / \mathrm{g} \\
\text { of tumour }\end{array}$ & [106] \\
\hline & PC (Mouse) & NA & PDC & $\begin{array}{c}\text { Drug accumulation observed in } \\
\text { tumour * }\end{array}$ & [123] \\
\hline & $\begin{array}{c}\text { PC (LS174T, } \\
\text { Human xenograft) }\end{array}$ & NA & PDC & $\begin{array}{c}\text { Drug accumulation observed in } \\
\text { tumour * }\end{array}$ & [124] \\
\hline & $\begin{array}{l}\text { PC (HT29, Human } \\
\text { xenograft) }\end{array}$ & NA & PDC & $\begin{array}{c}\text { Drug accumulation observed in } \\
\text { tumour * }\end{array}$ & [125] \\
\hline & $\begin{array}{l}\text { PC (HT29, Human } \\
\text { xenograft) }\end{array}$ & 111 & $\begin{array}{l}\text { Nano crystal } \\
(3 \mathrm{H}-\mathrm{PTX})\end{array}$ & $\begin{array}{l}\text { Low drug accumulation } \\
\text { observed in tumour * }\end{array}$ & [126] \\
\hline
\end{tabular}


Table 7. Cont.

\begin{tabular}{|c|c|c|c|c|c|}
\hline Tumour Type & $\begin{array}{c}\text { Clinical }(\mathbf{C}) / \\
\text { Pre-Clinical }(\mathbf{P C})\end{array}$ & $\begin{array}{l}\text { Sample } \\
\text { Size }(n)\end{array}$ & $\begin{array}{l}\text { Macromolecule } \\
\text { System Used }\end{array}$ & Remarks & Reference \\
\hline \multirow{4}{*}{$\begin{array}{l}\text { Head/Neck and } \\
\text { brain }\end{array}$} & $\mathrm{C}$ & 6 & PDC & $\begin{array}{c}2.2 \% \pm 2.1 \% \text { dose at } 2-3 \mathrm{~h} \\
1.3 \% \pm 0.4 \% \text { dose at } 24 \mathrm{~h} \\
0.5 \% \pm 0.3 \% \text { dose at } 8 \text { days } \\
\text { uptake in tumour }\end{array}$ & [4] \\
\hline & $\mathrm{C}$ & 10 & Liposome & $\begin{array}{l}13-19 \text { times higher } \\
\text { accumulation in tumour as } \\
\text { compared to the normal } \\
\text { brain tissue }\end{array}$ & [127] \\
\hline & $\mathrm{C}$ & 5 & Liposome & $\begin{array}{l}7-13 \text { times higher } \\
\text { accumulation in tumour as } \\
\text { compared to the normal } \\
\text { brain tissue }\end{array}$ & [127] \\
\hline & $\mathrm{C}$ & 7 & Liposome & $\begin{array}{l}33.0 \% \pm 15.8 \% \mathrm{ID} / \mathrm{Kg} \text { of } \\
\text { drug uptake in tumour }\end{array}$ & [97] \\
\hline \multicolumn{6}{|l|}{ Others } \\
\hline $\begin{array}{l}\text { Adenocarcinoma } \\
\text { (Unknown) }\end{array}$ & $\begin{array}{l}\text { PC (MAC 26, } \\
\text { Mouse) }\end{array}$ & NA & PDC & $\begin{array}{c}6.9 \%-10.8 \% \text { dose } / \mathrm{g} / \text { tumour } \\
\text { drug accumulation }\end{array}$ & [13] \\
\hline $\begin{array}{c}\text { Adenocarcinoma } \\
\text { (Unknown) }\end{array}$ & $\begin{array}{l}\text { PC (MAC 15A, } \\
\text { Mouse) }\end{array}$ & NA & PDC & $\begin{array}{c}8.2 \%-12.6 \% \text { dose } / \mathrm{g} / \text { tumour } \\
\text { drug accumulation }\end{array}$ & [13] \\
\hline Cervix & $\begin{array}{c}\text { PC (ME180, } \\
\text { Human xenograft) }\end{array}$ & NA & Liposome & $\begin{array}{l}\text { Drug accumulation observed } \\
\text { in tumour * } \\
\end{array}$ & [128] \\
\hline \multirow{4}{*}{ Fibrosarcoma } & $\begin{array}{c}\text { PC } \\
\text { (S-180, Mouse) }\end{array}$ & NA & Polymer conjugates & $\begin{array}{l}\text { Drug accumulation observed } \\
\text { in tumour * }\end{array}$ & [129] \\
\hline & $\begin{array}{c}\text { PC } \\
\text { (S-180, Mouse) }\end{array}$ & NA & Micelle & $\begin{array}{l}13 \text { fold higher drug } \\
\text { accumulation in tumour than } \\
\text { the free drug }\end{array}$ & {$[130]$} \\
\hline & $\begin{array}{c}\text { PC } \\
\text { (S-180, Mouse) }\end{array}$ & NA & PDC & $\begin{array}{l}\text { Drug accumulation observed } \\
\text { in tumour * }\end{array}$ & [131] \\
\hline & $\begin{array}{c}\text { PC } \\
\text { (S-180, Mouse) }\end{array}$ & NA & Protein-conjugate & $\begin{array}{l}\text { Drug accumulation observed } \\
\text { in tumour* }\end{array}$ & [10] \\
\hline \multirow{3}{*}{ Fibrosarcoma } & $\begin{array}{c}\text { PC } \\
\text { (Meth A, Mouse) }\end{array}$ & NA & PDC & $\begin{array}{l}\text { Drug accumulation observed } \\
\text { in tumour * }\end{array}$ & [132] \\
\hline & $\begin{array}{c}\text { PC } \\
\text { (S-180, Mouse) }\end{array}$ & NA & Protein-conjugate & $\begin{array}{c}4 \text { fold higher drug } \\
\text { accumulation in tumour than } \\
\text { the free drug }\end{array}$ & {$[8]$} \\
\hline & $\begin{array}{c}\text { PC } \\
\text { (S-180, Mouse) }\end{array}$ & NA & PDC & $\begin{array}{l}\text { Drug accumulation observed } \\
\text { in tumour * }\end{array}$ & [133] \\
\hline
\end{tabular}


Table 7. Cont.

\begin{tabular}{|c|c|c|c|c|c|}
\hline Tumour Type & $\begin{array}{c}\text { Clinical }(\mathbf{C}) / \\
\text { Pre-Clinical }(\mathbf{P C})\end{array}$ & $\begin{array}{l}\text { Sample } \\
\text { Size }(n)\end{array}$ & $\begin{array}{l}\text { Macromolecule } \\
\text { System Used }\end{array}$ & Remarks & Reference \\
\hline \multirow{6}{*}{ Liver } & $\mathrm{C}$ & 31 & Liposomes & $\begin{array}{c}\text { Low drug accumulation } \\
\text { observed in tumour * }\end{array}$ & [95] \\
\hline & $\mathrm{C}$ & 3 & Liposomes & $\begin{array}{c}\text { Low drug accumulation } \\
\text { observed in tumour } *\end{array}$ & [96] \\
\hline & PC (Mouse) & NA & Micelle & $\begin{array}{l}4 \text { fold higher drug } \\
\text { accumulation in tumour } \\
\text { than the free drug }\end{array}$ & {$[134]$} \\
\hline & PC (VX-2, Rabbit) & NA & $\begin{array}{l}\text { Polymer-protein } \\
\text { conjugate } \\
\text { (SMANCS-Lipidol) }\end{array}$ & $\begin{array}{l}\text { Drug accumulation } \\
\text { observed in tumour } *\end{array}$ & [135] \\
\hline & PC (VX-2, Rabbit) & NA & $\begin{array}{c}\text { Polymer-protein } \\
\text { conjugate (Lipidol) }\end{array}$ & $\begin{array}{l}\text { Drug accumulation } \\
\text { observed in tumour * }\end{array}$ & [136] \\
\hline & $\mathrm{PC}$ & NA & PDC & $\begin{array}{c}\text { Drug accumulation } \\
\text { observed in tumour * }\end{array}$ & {$[137]$} \\
\hline \multirow{4}{*}{ Prostate } & $\begin{array}{c}\text { PC } \\
\text { (Human } \\
\text { xenograft) }\end{array}$ & NA & $\begin{array}{l}{ }^{89} \mathrm{Zr}-\mathrm{DFO}-\mathrm{mAlb} \\
\text { (Polymer-protein } \\
\text { conjugate) }\end{array}$ & $\begin{array}{l}\text { Drug accumulation } \\
\text { observed in tumour * }\end{array}$ & [138] \\
\hline & $\begin{array}{l}\text { PC (Human } \\
\text { xenograft) }\end{array}$ & NA & PDC & $\begin{array}{c}\text { Drug accumulation } \\
\text { observed in tumour * }\end{array}$ & [139] \\
\hline & PC (Rat) & NA & PDC & $\begin{array}{c}\text { Drug accumulation } \\
\text { observed in tumour * }\end{array}$ & {$[140]$} \\
\hline & PC (Rat) & NA & PDC & $\begin{array}{c}\text { Drug accumulation } \\
\text { observed in tumour * }\end{array}$ & {$[141]$} \\
\hline
\end{tabular}

Notes: * The quantitative data on accumulation in tumour is not available in the original research paper; ${ }^{*}$ related free drug uptake is not stated in the original study; " $n$ " = number of human/animal subjects.

Two decades since the first PDC entered the clinical evaluation [2], one might wonder about the margin of advantage of PDCs over their corresponding parent drugs in terms of overall survival and the patient's quality of life. Such an advantage of a drug is evaluated only at phase III of the clinical trial, thus since only 2 PDCs have undergone phase III clinical trials (Opaxio and NKTR-102) and the clinical data is available to-date only for Opaxio, any conclusion with regards to the overall survival and patient's quality of life is derived from Opaxio's performance. Opaxio, in comparison with its conventional paclitaxel-based treatment, showed some safety-related advantages such as alopecia was rare, nausea and vomiting were uncommon and hypersensitivity reactions were rarely observed. A significant survival benefit has also been observed for women receiving Opaxio vs. paclitaxel [7]. These promising results have provided the confidence that PDCs can give therapeutic benefits in the field of oncology. The use of PDCs in combination with the application of diagnostic tools to measure protease expression and EPR effect would be a rational approach for the further development and clinical use of PDCs. 


\section{Conclusions}

In this study, we have reported analysis of data from the literature whereby we have documented and examined the expression of enzymes (cathepsins) within various tumour types, the magnitude of the EPR effect in the various tumour types, and the clinical responses observed for PDCs. We have determined that the highest percentages of clinical responses to PDCs were observed for lung cancer, which was also found to express high levels of the cathepsin enzymes. Breast and ovarian cancer also showed high clinical responses to PDCs, which correlated well with high levels of cathepsins observed in these tumour types, and with reports indicating the presence of the EPR effect. This finding is in line with other studies $[13,14]$ and in agreement with that concluded by others (e.g., [13]). Moreover, our study also suggests that careful patient selection, in the form of pre-screening for enzyme content and the EPR effect, would be a rational approach for the further development and clinical application of PDCs. This could ultimately result in a more consistent efficacy of this drug delivery system in the clinical setting.

\section{Acknowledgments}

Financial support from the Indian Government (A.K.R.) and the Felix Trust (D.R.) is gratefully acknowledged.

\section{Author Contributions}

A.K.R. and D.R. jointly carried out the research and wrote the manuscript; H.M.I.O. co-led the research and writing of the manuscript; F.G. conceived the original idea, led the research and writing of the manuscript.

\section{Conflicts of Interest}

The authors declare no conflict of interest.

\section{References}

1. Duncan, R. Polymer conjugates as anticancer nanomedicines. Nat. Rev. Cancer 2006, 6, 688-701.

2. Duncan, R.; Gaspar, R. Nanomedicine(s) under the microscope. Mol. Pharm. 2011, 8, 2101-2141.

3. Maeda, H.; Nakamura, H.; Fang, J. The EPR effect for macromolecular drug delivery to solid tumors: Improvement of tumor uptake, lowering of systemic toxicity, and distinct tumor imaging in vivo. Adv. Drug Deliv. Rev. 2013, 65, 71-79.

4. Vasey, P.A.; Kaye, S.B.; Morrison, R.; Twelves, C.; Wilson, P.; Duncan, R.; Thomson, A.H.; Murray, L.S.; Hilditch, T.E.; Murray, T.; et al. Phase I clinical and pharmacokinetic study of PK1 [N-(2-hydroxypropyl) methacrylamide copolymer doxorubicin]: First member of a new class of chemotherapeutic agents-Drug-polymer conjugates. Clin. Cancer. Res. 1999, 5, 83-94. 
5. Albain, K.S.; Belani, C.P.; Bonomi, P.; O’Byrne, K.J.; Schiller, J.H.; Socinski, M. PIONEER: A phase III randomized trial of paclitaxel poliglumex versus paclitaxel in chemotherapy-naive women with advanced-stage non-small-cell lung cancer and performance status of 2. Clin. Lung Cancer 2006, 7, 417-419.

6. $\quad$ Langer, C.J.; O’Byrne, K.J.; Socinski, M.A.; Mikhailov, S.M.; Leśniewski-Kmak, K.; Smakal, M.; Ciuleanu, T.E.; Orlov, S.V.; Dediu, M.; Heigener, D.; et al. Phase III trial comparing paclitaxel poliglumex (CT-2103, PPX) in combination with carboplatin vs. standard paclitaxel and carboplatin in the treatment of PS 2 patients with chemotherapy-naïve advanced non-small cell lung cancer. J. Thorac. Oncol. 2008, 3, 623-630.

7. Li, C.; Wallace, S. Polymer-drug conjugates: Recent development in clinical oncology. Adv. Drug Deliv. Rev. 2008, 60, 886-898.

8. Matsumura, Y.; Maeda, H. A New Concept for macromolecular therapeutics in cancer chemotherapy: Mechanism of tumoritropic accumulation of proteins and the antitumor agent smancs. Cancer Res. 1986, 46, 6387-6392.

9. Maeda, H.; Bharate, G.Y.; Daruwalla, J. Polymeric drugs for efficient tumor-targeted drug delivery based on EPR-effect. Eur. J. Pharm. Biopharm. 2009, 71, 409-419.

10. Maeda, H. Tumor-selective delivery of macromolecular drugs via the EPR effect: Background and future prospects. Bioconjug. Chem. 2010, 21, 797-802.

11. Maeda, H.; Matsumura, Y. EPR effect based drug design and clinical outlook for enhanced cancer chemotherapy. Adv. Drug Deliv. Rev. 2011, 63, 129-130.

12. Fang, J.; Nakamura, H.; Maeda, H. The EPR effect: Unique features of tumor blood vessels for drug delivery, factors involved, and limitations and augmentation of the effect. Adv. Drug Deliv. Rev. 2011, 63, 136-151.

13. Duncan, R.; Sat-Klopsch, Y.N.; Burger, A.M.; Bibby, M.C.; Fiebig, H.H.; Sausville, E.A. Validation of tumour models for use in anticancer nanomedicine evaluation: The EPR effect and cathepsin B-mediated drug release rate. Cancer Chemother. Pharmacol. 2013, 72, 417-427.

14. Prabhakar, U.; Maeda, H.; Jain, R.K.; Sevick-Muraca, E.M.; Zamboni, W.; Farokhzad, O.C.; Barry, S.T.; Gabizon, A.; Grodzinski, P.; Blakey, D.C. Challenges and key considerations of the enhanced permeability and retention effect for nanomedicine drug delivery in oncology. Cancer Res. 2013, 73, 2412-2417.

15. Duncan, R. The dawning era of polymer therapeutics. Nat. Rev. Drug Discov. 2003, 2, 347-360.

16. Satchi, R.; Connors, T.A.; Duncan, R. PDEPT: Polymer directed enzyme prodrug therapy. I. HPMA copolymer-cathepsin B and PK1 as a model combination. Br. J. Cancer 2001, 85, 1070-1076.

17. Zhong, Y.J.; Shao, L.H.; Li, Y. Cathepsin B-cleavable doxorubicin prodrugs for targeted cancer therapy. Int. J. Oncol. 2013, 42, 373-383.

18. Chipman, S.D.; Oldham, F.B.; Pezzoni, G.; Singer, J.W. Biological and clinical characterization of paclitaxel poliglumex (PPX, CT-2103), a macromolecular polymer-drug conjugate. Int. J. Nanomed. 2006, 1, 375-383. 
19. Ross, H.; Bonomi, P.; Langer, C.; O’Brien, M.; O’Byrne, K.; Paz-Ares, L.; Sandler, A.; Socinski, M.; Oldham, F.; Singer, J. Effect of gender on outcome in two randomized phase III trials of paclitaxel poliglumex (PPX) in chemo-naïvepts with advanced NSCLC and poor performance status (PS2). J. Clin. Oncol. 2006, 24, Abstract 7039.

20. Seymour, L.W.; Ferry, D.R.; Kerr, D.J.; Rea, D.; Whitlock, M.; Poyner, R.; Boivin, C.; Hesslewood, S.; Twelves, C.; Blackie, R.; et al. Phase II studies of polymer-doxorubicin (PK1, FCE28068) in the treatment of breast, lung and colorectal cancer. Int. J. Oncol. 2009, 6, 1629-1636.

21. Seymour, L.W.; Ferry, D.R.; Anderson, D.; Hesslewood, S.; Julyan, P.J.; Poyner, R.; Doran, J.; Young, A.M.; Burtles, S.; Kerr, D.J. Hepatic drug targeting: Phase I evaluation of polymer-bound doxorubicin. J. Clin. Oncol. 2002, 20, 1668-1676.

22. Soepenberg, O.; de Jonge, M.J.; Sparreboom, A.; de Bruin, P.; Eskens, F.A.; de Heus, G.; Wanders, J.; Cheverton, P.; Ducharme, M.P.; Verweij, J. Phase I and pharmacokinetic study of DE-310 in patients with advanced solid tumors. Clin. Cancer Res. 2005, 11, 703-711.

23. Veltkamp, S.A.; Witteveen, E.O.; Capriati, A.; Crea, A.; Animati, F.; Voogel-Fuchs, M.; van den Heuvel, I.J.; Beijnen, J.H.; Voest, E.E.; Schellens, J.H. Clinical and pharmacologic study of the novel prodrug delimotecan (MEN 4901/T-0128) in patients with solid tumors. Clin. Cancer Res. 2008, 14, 7535-7544.

24. Homsi, J.; Simon, G.R.; Garrett, C.R.; Springett, G.; de Conti, R.; Chiappori, A.A.; Munster, P.N.; Burton, M.K.; Stromatt, S.; Allievi, C.; et al. Phase I trial of poly-L-glutamate camptothecin (CT-2106) administered weekly in patients with advanced solid malignancies. Clin. Cancer Res. 2007, 13, 5855-5861.

25. Galic, V.L.; Wright, J.D.; Lewin, S.N.; Herzog, T.J. Paclitaxel poliglumex for ovarian cancer. Expert Opin. Invest. Drugs. 2011, 20, 813-821.

26. Veronese, M.L.; Flaherty, K.; Kramer, A.; Konkle, B.A.; Morgan, M.; Stevenson, J.P.; O'Dwyer, P.J. Phase I study of the novel taxane CT-2103 in patients with advanced solid tumors. Cancer Chemother. Pharmacol. 2005, 55, 497-501.

27. Amato, R.J.; Khan, M.M.T. Phase II study of paclitaxel poliglumex (PPX) for androgen independent prostate cancer (AIPC). In Proceedings of the American Society of Clinial Oncology (ASCO), Prostate Cancer Symposium, Alexandria, VA, USA, 2007; Abstract 243.

28. Singer, J.W.; Bhatt, R.; Tulinsky, J.; Buhler, K.R.; Heasley, E.; Klein, P.; de Vries, P. Water-soluble poly-(L-glutamic acid)-Gly-camptothecin conjugates enhance camptothecin stability and efficacy in vivo. J. Control. Release 2001, 74, 243-247.

29. Nemunaitis, J.; Cunningham, C.; Senzer, N.; Gray, M.; Oldham, F.; Pippen, J.; Mennel, R.; Eisenfeld, A. Phase I study of CT-2103, a polymer-conjugated paclitaxel, and carboplatin in patients with advanced solid tumors. Cancer Invest. 2005, 23, 671-676.

30. Boddy, A.V.; Plummer, E.R.; Todd, R.; Sludden, J.; Griffin, M.; Robson, L.; Cassidy, J.; Bissett, D.; Bernareggi, A.; Verrill, M.W.; et al. A phase I and pharmacokinetic study of paclitaxel poliglumex (XYOTAX), investigating both 3-weekly and 2-weekly schedules. Clin. Cancer Res. 2005, 11, 7834-7840. 
31. Dipetrillo, T.; Milas, L.; Evans, D.; Akerman, P.N.T.; Miner, T.; Cruff, D.; Chauhan, B.; Iannitti, D.; Harrington, D.; Safran, H. Paclitaxel poliglumex (PPX-Xyotax) and concurrent radiation for esophageal and gastric cancer: A phase I study. Am. J. Clin. Oncol. 2006, 29, 376-379.

32. Lin, N.U.; Parker, L.M.; Come, S.E.; Burstein, H.J.; Haldoupis, M.; Ryabin, N.; Gelman, R.; Winer, E.P.; Shulman, L.N. Phase II study of CT-2103 as first- or second-line chemotherapy in patients with metastatic breast cancer: Unexpected incidence of hypersensitivity reactions. Invest. New Drugs 2007, 25, 369-375.

33. Sabbatini, P.; Sill, M.W.; O’Malley, D.; Adler, L.; Secord, A.A. A phase II trial of paclitaxel poliglumex in recurrent or persistent ovarian or primary peritoneal cancer (EOC): A Gynecologic Oncology Group Study. Gynecol. Oncol. 2008, 111, 455-460.

34. Bonomi, P. Paclitaxel poliglumex (PPX, CT-2103): Macromolecular medicine for advanced non-small-cell lung cancer. Expert Rev. Anticancer Ther. 2007, 7, 415-422.

35. Rademaker-Lakhai, J.M.; Terret, C.; Howell, S.B.; Baud, C.M.; de Boer, R.F.; Pluim, D.; Beijnen, J.H.; Schellens, J.H.; Droz, J.P. A phase pharmacological and I study of the platinum polymer AP5280 given as an intravenous infusion once every 3 weeks in patients with solid tumors. Clin. Cancer Res. 2004, 10, 3386-3395.

36. Campone, M.; Rademaker-Lakhai, J.M.; Bennouna, J.; Howell, S.B.; Nowotnik, D.P.; Beijnen, J.H.; Schellens, J.H. Phase I and pharmacokinetic trial of AP5346, a DACH-platinum-polymer conjugate, administered weekly for three out of every 4 weeks to advanced solid tumor patients. Cancer Chemother Pharmacol. 2007, 60, 523-533.

37. Terwogt, J.M.M.; Bokkel Huinink, W.W.; Schellens, J.H.; Schot, M.; Mandjes, I.A.; Zurlo, M.G.; Rocchetti, M.; Rosing, H.; Koopman, F.J.; Beijnen, J.H. Phase I clinical and pharmacokinetic study of PNU166945, a novel water-soluble polymer-conjugated prodrug of paclitaxel. Anticancer Drugs 2001, 12, 315-323.

38. Schoemaker, N.E.; van Kesteren, C.; Rosing, H.; Jansen, S.; Swart, M.; Lieverst, J.; Fraier, D.; Breda, M.; Pellizzoni, C.; Spinelli, R.; et al. A phase I and pharmacokinetic study of MAG-CPT, a water-soluble polymer conjugate of camptothecin. Br. J. Cancer 2002, 87, 608-614.

39. Bissett, D.; Cassidy, J.; de Bono, J.S.; Muirhead, F.; Main, M.; Robson, L.; Fraier, D.; Magnè, M.L.; Pellizzoni, C.; Porro, M.G.; et al. Phase I and pharmacokinetic (PK) study of MAG-CPT (PNU 166148): A polymeric derivative of camptothecin (CPT). Br. J. Cancer 2004, $91,50-55$.

40. Wachters, F.M.; Groen, H.J.; Maring, J.G.; Gietema, J.A.; Porro, M.; Dumez, H.; de Vries, E.G.; van Oosterom, A.T. A phase I study with MAG-camptothecin intravenously administered weekly for 3 weeks in a 4-week cycle in adult patients with solid tumours. Br. J. Cancer 2004, 90, 2261-2267.

41. Rowinsky, E.K.; Rizzo, J.; Ochoa, L.; Takimoto, C.H.; Forouzesh, B.; Schwartz, G.; Hammond, L.A.; Patnaik, A.; Kwiatek, J.; Goetz, A.; et al. A phase I and pharmacokinetic study of pegylatedcamptothecin as a 1-h infusion every 3 weeks in patients with advanced solid malignancies. J. Clin. Oncol. 2003, 21, 148-157. 
42. Posey, J.A; Saif, M.W.; Carlisle, R.; Goetz, A.; Rizzo, J.; Stevenson, S.; Rudoltz, M.S.; Kwiatek, J.; Simmons, P.; Rowinsky, E.K.; et al. Phase 1 study of weekly polyethylene glycol-camptothecin in patients with advanced solid tumors and lymphomas. Clin. Cancer Res. 2005, 11, 7866-7871.

43. Scott, L.C.; Yao, J.C.; Thomas, A.L.; Falk, S.; Mena, R.R.; Picus, J.; Wright, J.; Mulcahy, M.F.; Ajani, J.A.; Evans, T.R. A phase II study of pegylated-camptothecin (pegamotecan) in the treatment of locally advanced and metastatic gastric and gastro-oesophageal junction adenocarcinoma. Cancer Chemother. Pharmacol. 2009, 63, 363-370.

44. Beeram, M.; Rowinsky, E.K.; Hammond, L.A.; Patnaik, A.; Schwartz, G.H.; de Bono, J.S.; Forero, L.; Forouzesh, B.; Berg, K.E.; Rubin, E.H.; et al. A phase I pharmacokinetic (PK) study of PEG-paclitaxel in patients with advanced solid tumors. Proc. Am. Soc. Clin. Oncol. 2002, 21, 405.

45. Patnaik, A.; Papadopoulos, K.P.; Tolcher, A.W.; Beeram, M.; Urien, S.; Schaaf, L.J.; Tahiri, S.; Bekaii-Saab, T.; Lokiec, F.M.; Rezaï, K.; et al. Phase I dose-escalation study of EZN-2208 (PEG-SN38), a novel conjugate of poly(ethylene) glycol and SN38, administered weekly in patients with advanced cancer. Cancer Chemother. Pharmacol. 2013, 71, 1499-1506.

46. Garrett, C.R.; Bekaii-Saab, T.S.; Ryan, T.; Fisher, G.A.; Clive, S.; Kavan, P.; Shacham-Shmueli, E.; Buchbinder, A.; Goldberg, R.M. Randomized phase 2 study of pegylated SN-38 (EZN-2208) or irinotecan plus cetuximab in patients with advanced colorectal cancer. Cancer 2013, 119, 4223-4230.

47. Von Hoff, D.D.; Jameson, G.S.; Borad, M.J.; Rosen, L.S.; Utz, J.; Basche, M.; Alemany, C.; Dhar, S.; Acosta, L.; Barker, T.; et al. First phase I trial of NKTR-102 (PEG-irinotecan) reveals early evidence of broad anti-tumor activity in three different schedules. Available online: https://www.nektar.com/pdf/pipeline/NKTR-102/NKTR-102_poster_595.pdf (accessed on 3 November 2013).

48. Vergote, I.B.; Garcia, A.; Micha, J.; Pippitt, C.; Bendell, J.; Spitz, D.; Reed, N.; Dark, G.; Fracasso, P.M.; Ibrahim, E.N.; et al. Randomized multicenter phase II trial comparing two schedules of etirinotecan pegol (NKTR-102) in women with recurrent platinum-resistant/ refractory epithelial ovarian cancer. J. Clin. Oncol. 2013, 31, 4060-4066.

49. Awada, A.; Garcia, A.A.; Chan, S.; Jerusalem, G.H.; Coleman, R.E.; Huizing, M.T.; Mehdi, A.; O’Reilly, S.M.; Hamm, J.T.; Barrett-Lee, P.J.; et al. Two schedules of etirinotecan pegol (NKTR-102) in patients with previously treated metastatic breast cancer: A randomised phase 2 study. Lancet Oncol. 2013, 14, 1216-1225.

50. Etirinotecan pegol (NKTR-102). Available online: http://www.nektar.com/product_pipeline/ oncology_nktr-102.html (accessed on 15 May 2014).

51. Calvo, E.; Hoch, U.; Maslyar, D.J.; Tolcher, A.W. Dose-escalation phase I study of NKTR-105, a novel pegylated form of docetaxel. J. Clin. Oncol. 2010, 28, 15.

52. Sausville, E.A.; Garbo, L.; Weiss, G.J.; Shkolny, D.; Yurkovetskiy, A.V.; Bethune, C.; Ramanathan, R.K.; Fram, R.J. Phase 1 study of XMT-1001, a novel water soluble camptothecin conjugate, given as an intravenous infusion once every three weeks to patients with advanced solid tumors. Mol. Cancer Ther. 2009, 8, 12. 
53. Weiss, G.J.; Chao, J.; Neidhart, J.D.; Ramanathan, R.K.; Bassett, D.; Neidhart, J.A.; Choi, C.H.; Chow, W.; Chung, V.; Forman, S.J.; et al. First-in-human phase 1/2a trial of CRLX101, a cyclodextrin-containing polymer-camptothecinnanopharmaceutical in patients with advanced solid tumor malignancies. Invest. New Drugs 2013, 31, 986-1000.

54. Bassi, P.F.; Volpe, A.; D’Agostino, D.; Palermo, G.; Renier, D.; Franchini, S.; Rosato, A.; Racioppi, M. Paclitaxel-hyaluronic acid for intravesical therapy of bacillus Calmette-Guérin refractory carcinoma in situ of the bladder: Results of a phase I study. J. Urol. 2011, 185, 445-449.

55. Danhauser-Riedl, S.; Hausmann, E.; Schick, H.D.; Bender, R.; Dietzfelbinger, H.; Rastetter, J.; Hanauske, A.R. Phase I clinical and pharmacokinetic trial of dextran-conjugated doxorubicin (AD-70, DOX-O.XD). Invest. New Drugs 1993, 11, 187-195.

56. Duncan, R. Development of HPMA copolymer-anticancer conjugates: Clinical experience and lessons learnt. Adv. Drug Deliv. Rev. 2009, 61, 1131-1148.

57. Pasut, G.; Veronese, F.M. PEG conjugates in clinical development or use as anticancer agents: An overview. Adv. Drug Deliv. Rev. 2009, 61, 1177-1188.

58. Podgorski, I.; Sloane, B.F. Cathepsin B and its role(s) in cancer progression. Biochem. Soc. Symp. 2003, 70, 263-276.

59. Eisenhauer, E.A.; Therasse, P.; Bogaerts, J.; Schwartz, L.H.; Sargent, D.; Ford, R.; Dancey, J.; Arbuck, S.; Gwyther, S.; Mooney, M.; et al. New response evaluation criteria in solid tumours: Revised RECIST guideline (version 1.1). Eur. J. Cancer 2009, 45, 228-247.

60. Gocheva, V.; Joyce, J.A. Cysteine cathepsins and the cutting edge of cancer invasion. Cell Cycle 2007, 6, 60-64.

61. Sloane, B.F.; Dunn, J.R.; Honn, K.V. Lysosomal cathepsin B: Correlation with metastatic potential. Science 1981, 212, 1151-1153.

62. Turk, V.; Kos, J.; Turk, B. Cysteine cathepsins (proteases)—On the main stage of cancer? Cancer Cell 2004, 5, 409-410.

63. Mohamed, M.M.; Sloane, B.F. Cysteine cathepsins: Multifunctional enzymes in cancer. Nat. Rev. Cancer 2006, 6, 764-775.

64. Duncan, R.; Kopecková-Rejmanová, P.; Strohalm, J.; Hume, I.; Cable, H.C.; Pohl, J.; Lloyd, J.B.; Kopecek, J. Anticancer agents coupled to $N$-(2-hydroxypropyl)methacrylamide copolymers. I. Evaluation of daunomycin and puromycin conjugates in vitro. Br. J. Cancer 1987, 55, 165-174.

65. Putnam, D.; Shiah, J.G.; Kopecek, J. Intra cellularly biorecognizable derivatives of 5-fluorouracil: Implications of targetable delivery in the human condition, Biochem. Pharmacol. 1996, 52, 957-962.

66. Chen, Q.; Fei, J.; Wu, L.; Jiang, Z.; Wu, Y.; Zheng, Y.; Lu, G. Detection of cathepsin B, cathepsin $\mathrm{L}$, cystatin $\mathrm{C}$, urokinase plasminogen activator and urokinase plasminogen activator receptor in the sera of lung cancer patients. Oncol. Lett. 2011, 2, 693-699.

67. Smith, V.; Wirth, G.J.; Fiebig, H.H.; Burger, A.M. Tissue microarrays of human tumorxenografts: Characterization of proteins involved in migration and angiogenesis for applications in the development of targeted anticancer agents. Cancer Genomics Proteomics 2008, 5, 263-273.

68. Ledakis, P.; Tester, W.T.; Rosenberg, N.; Romero-Fischmann, D.; Daskal, I.; Lah, T.T. Cathepsins D, B, and L in malignant human lung tissue. Clin. Cancer Res. 1996, 2, 561-568. 
69. Kos, J.; Sekirnik, A.; Kopitar, G.; Cimerman, N.; Kayser, K.; Stremmer, A.; Fiehn, W.; Werle, B. Cathepsin $\mathrm{S}$ in tumours, regional lymph nodes and sera of patients with lung cancer: Relation to prognosis. Br. J. Cancer 2001, 85, 1193-1200.

70. Schweiger, A.; Staib, A.; Werle, B.; Krasovec, M.; Lah, T.T.; Ebert, W.; Turk, V.; Kos, J. Cysteine proteinase cathepsin $\mathrm{H}$ in tumours and sera of lung cancer patients: Relation to prognosis and cigarette smoking. Br. J. Cancer 2000, 82, 782-788.

71. Li, C.; Chen, L.; Wang, J.; Zhang, L.; Tang, P.; Zhai, S.; Guo, W.; Yu, N.; Zhao, L.; Liu, M.; et al. Expression and clinical significance of cathepsin B and stefin A in laryngeal cancer. Oncol. Rep. 2011, 26, 869-875.

72. Saleh, Y.; Wnukiewicz, J.; Andrzejak, R.; Trziszka, T.; Siewinski, M.; Ziolkowski, P.; Kopec, W. Cathepsin B and cysteine protease inhibitors in human tongue cancer: Correlation with tumor staging and in vitro inhibition of cathepsin B by chicken cystatin. J. Cancer Mol. 2006, 2, 67-72.

73. Shuja, S.; Cai, J.; Iacobuzio-Donahue, C.; Zacks, J.; Beazley, R.M.; Kasznica, J.M.; O’Hara, C.J.; Heimann, R.; Murnane, M.J. Cathepsin B activity and protein levels in thyroid carcinoma, Graves' disease, and multinodular goiters. Thyroid 1999, 9, 569-577.

74. Demchik, L.L.; Sameni, M.; Nelson, K.; Mikkelsen, T.; Sloane, B.F. Cathepsin B and glioma invasion. Int. J. Dev. Neurosci. 1999, 17, 483-494.

75. Rempel, S.A.; Rosenblum, M.L.; Mikkelsen, T.; Yan, P.S.; Ellis, K.D.; Golembieski, W.A.; Sameni, M.; Rozhin, J.; Ziegler, G.; Sloane, B.F. Cathepsin B expression and localization in glioma progression and invasion. Cancer Res. 1994, 54, 6027-6031.

76. Gole, B.; Huszthy, P.C.; Popović, M.; Jeruc, J.; Ardebili, Y.S.; Bjerkvig, R.; Lah, T.T. The regulation of cysteine cathepsins and cystatins in human gliomas. Int. J. Cancer 2012, 131, 1779-1789.

77. Fan, K.; Zhang, Y.; Song, D.; Zhang, Y.; Ma, J. Relation of cystatin C and cathepsin B expression to the pathological grade and invasion of human gliomas. Chin. J. Clin. Oncol. 2007, 4, 303-306.

78. Sivaparvathi, M.; Sawaya, R.; Chintala, S.K.; Go, Y.; Gokaslan, Z.L.; Rao, J.S. Expression of cathepsin D during the progression of human gliomas. Neurosci. Lett. 1996, 208, 171-174.

79. Sivaparvathi, M.; Sawaya, R.; Gokaslan, Z.L.; Chintala, S.K.; Rao, J.S. Expression and the role of cathepsin H in human glioma progression and invasion. Cancer Lett. 1996, 104, 121-126.

80. Plebani, M.; Herszènyi, L.; Cardin, R.; Roveroni, G.; Carraro, P.; Paoli, M.D.; Rugge, M.; Grigioni, W.F.; Nitti, D.; Naccarato, R. Cysteine and serine proteases in gastric cancer. Cancer 1995, 76, 367-375.

81. Herszényi, L.; István, G.; Cardin, R.; de Paoli, M.; Plebani, M.; Tulassay, Z.; Farinati, F. Serum cathepsin B and plasma urokinase-type plasminogen activator levels in gastrointestinal tract cancers. Eur. J. Cancer Prev. 2008, 17, 438-445.

82. Herszènyi, L.; Plebani, M.; Carraro, P.; de Paoli, M.; Roveroni, G.; Cardin, R.; Tulassay, Z.; Naccarato, R.; Farinati, F. The role of cysteine and serine proteases in colorectal carcinoma. Cancer 1999, 86, 1135-1142.

83. Doxakis, A.; Maria, A.; Savvas, P.; Zafiroula, I.K. Assessment of the Roles of Cathepsins B, H and $\mathrm{L}$ in the progression of colorectal cancer. J. Cancer Ther. 2013, 4, 1-7. 
84. Hazen, L.G.; Bleeker, F.E.; Lauritzen, B.; Bahns, S.; Song, J.; Jonker, A.; van Driel, B.E.; Lyon, H.; Hansen, U.; Köhler, A.; et al. Comparitive localization of cathepsin B protein and activity in colorectal cancer. J. Histochem. Cytochem. 2000, 48, 1421-1430.

85. Vizin, T.; Christensen, I.J.; Nielsen, H.J.; Kos, J. Cathepsin X in serum from patients with colorectal cancer: Relation to prognosis. Radiol. Oncol. 2012, 46, 207-212.

86. Bremer, C.; Tung, C.H.; Bogdanov, A.; Weissleder, R., Jr. Imaging of differential protease expression in breast cancers for detection of aggressive tumor phenotypes. Radiology 2002, 222, 814-818.

87. Hulkower, K.I.; Butler, C.C.; Linebaugh, B.E.; Klaus, J.L.; Keppler, D.; Giranda, V.L.; Sloane, B.F. Fluorescent microplate assay for cancer cell-associated cathepsin B. Eur. J. Biochem. 2000, 267, 4165-4170.

88. Ruibal, A.; Herranz, M.; Arias, J.I. Clinical and biological significance of cathepsin D levels in breast cancer cytosol in women over 70 years. Biomark. Cancer 2012, 4, 1-6.

89. Pečar Fonović, U.; Jevnikar, Z.; Rojnik, M.; Doljak, B.; Fonović, M.; Jamnik, P.; Kos, J. Profilin 1 as a target for cathepsin X activity in tumor cells. PLoS One 2013, 8, e53918.

90. Zhang, W.; Hu, X.X.; Yang, X.Z.; Wang, Q.; Cheng, H.; Wang, S.M.; Hu, Y.L.; Yang, Z.J.; $\mathrm{Li}, \mathrm{L}$. Combined detection of serum matrix metalloproteinase 9, acetyl heparinase and cathepsin $\mathrm{L}$ in diagnosis of ovarian cancer. Chin. J. Cancer Res. 2012, 24, 67-71.

91. Gopinathan, A.; Denicola, G.M.; Frese, K.K.; Cook, N.; Karreth, F.A.; Mayerle, J.; Lerch, M.M.; Reinheckel, T.; Tuveson, D.A. Cathepsin B promotes the progression of pancreatic ductal adenocarcinoma in mice. Gut 2012, 61, 877-884.

92. Brix, K.; Dunkhorst, A.; Mayer, K.; Jordans, S. Cysteine cathepsins: Cellular roadmap to different functions. Biochimie 2008, 90, 194-207.

93. Kartz, F.; Senter, P.; Steinhagam, H. Drug Delivery in Oncology; Wiley-VCH-Verlag \& Co. KGaA: Weinheim, Germany, 2012; pp. 875-876.

94. Maeda, H. Vascular permeability in cancer and infection as related to macromolecular drug delivery, with emphasis on the EPR effect for tumor-selective drug targeting. Proc. Jpn. Acad. B Phys. Biol. Sci. 2012, 88, 53-71.

95. Maki, S.; Konno, T.; Maeda, H. Image enhancement in computerized tomography for sensitive diagnosis of liver cancer and semiquantitation of tumor selective drug targeting with oily contrast medium. Cancer 1985, 56, 751-757.

96. Nagamitsu, A.; Greish, K.; Maeda, H. Elevating blood pressure as a strategy to increase tumortargeted delivery of macromolecular drug SMANCS: Cases of advanced solid tumors. Jpn. J. Clin. Oncol. 2009, 39, 756-766.

97. Harrington, K.J.; Mohammadtaghi, S.; Uster, P.S.; Glass, D.; Peters, A.M.; Vile, R.G.; Stewart, J.S. Effective targeting of solid tumors in patients with locally advanced cancers by radiolabeled pegylatedliposomes. Clin. Cancer Res. 2001, 7, 243-254.

98. Gabizon, A.; Catane, R.; Uziely, B.; Kaufman, B.; Safra, T.; Cohen, R.; Martin, F.; Huang, A.; Barenholz, Y. Prolonged circulation time and enhanced accumulation in malignant exudates of doxorubicin encapsulated in polyethylene-glycol coated liposomes. Cancer Res. 1994, 54, 987-992. 
99. Desai, N.; Trieu, V.; Yao, Z.; Louie, L.; Ci, S.; Yang, A.; Tao, C.; de, T.; Beals, B.; Dykes, D.; et al. Increased antitumor activity, intratumor paclitaxel concentrations, and endothelial cell transport of cremophor-free, albumin-bound paclitaxel, ABI-007, compared with cremophor-based paclitaxel. Clin. Cancer Res. 2006, 12, 1317-1324.

100. Pimm, M.V.; Perkins, A.C.; Strohalm, J.; Ulbrich, K.; Duncan, R. Gamma scintigraphy of the biodistribution of ${ }^{123}$ I-labelled $N$-(2-hydroxypropyl)methacrylamide copolymer-doxorubicin conjugates in mice with transplanted melanoma and mammary carcinoma. J. Drug Target 1996, 3, 375-383.

101. Sapra, P.; Zhao, H.; Mehlig, M.; Malaby, J.; Kraft, P.; Longley, C.; Greenberger, L.M.; Horak, I.D. Novel delivery of SN38 markedly inhibits tumor growth in xenografts, including a camptothecin-11-refractory model. Clin. Cancer Res. 2008, 14, 1888-1986.

102. Li, C.J.; Miyamoto, Y.; Kojima, Y.; Maeda, H. Augmentation of tumour delivery of macromolecular drugs with reduced bone marrow delivery by elevating blood pressure. Br. J. Cancer 1993, 67, 975-980.

103. Kommareddy, S.; Amiji, M. Preparation and evaluation of thiol-modified gelatin nanoparticles for intracellular DNA delivery in response to glutathione. Bioconjug. Chem. 2005, 16, 1423-1432.

104. Cabrala, H.; Murakamia, M.; Hojob, H.; Teradac, Y.; Kanod, M.R.; Chunga, U.; Nishiyamae, N.; Kataokaa, K. Targeted therapy of spontaneous murine pancreatic tumors by polymeric micelles prolongs survival and prevents peritoneal metastasis. Proc. Natl. Acad. Sci. USA 2013, 110, 11397-11402.

105. Koukourakis, M.I.; Koukouraki, S.; Giatromanolaki, A.; Archimandritis, S.C.; Skarlatos, J.; Beroukas, K.; Bizakis, J.G.; Retalis, G.; Karkavitsas, N.; Helidonis, E.S. Liposomal doxorubicin and conventionally fractionated radiotherapy in the treatment of locally advanced non-small-cell lung cancer and head and neck cancer. J. Clin. Oncol. 1999, 17, 3512-3521.

106. Gabizon, A.; Price, D.C.; Huberty, J.; Bresalier, R.S.; Papahadjopoulos, D. Effect of liposome composition and other factors on the targeting of liposomes to experimental tumors: Biodistribution and imaging studies. Cancer Res. 1990, 50, 6371-6378.

107. Kim, S.C.; Kim, D.W.; Shim, Y.H.; Bang, J.S.; Oh, H.S.; Wan Kim, S.; Seo, M.H. In vivo evaluation of polymeric micellar paclitaxel formulation: Toxicity and efficacy. J. Control Release 2001, 191-202.

108. Veronese, F.M.; Schiavon, O.; Pasut, G.; Mendichi, R.; Andersson, L.; Tsirk, A.; Ford, J.; Wu, G.; Kneller, S.; Davies, J.; et al. PEG-doxorubicin conjugates: Influence of polymer structure on drug release, in vitro cytotoxicity, biodistribution, and antitumor activity. Bioconjug. Chem. 2005, 16, 775-784.

109. Sano, K.; Nakajima, T.; Choyke, P.L.; Kobayashi, H. Markedly enhanced permeability and retention effects induced by photo-immunotherapy of tumors. ACS Nano 2013, 7, 717-724.

110. Gianasi, E.; Wasil, M.; Evagorou, E.G.; Keddle, A.; Wilson, G.; Duncan, R. HPMA copolymer platinates as novel antitumour agents: In vitro properties, pharmacokinetics and antitumour activity in vivo. Eur. J. Cancer 1999, 35, 994-1002. 
111. Rice, J.R.; Gerberas, J.L.; Nowotnik, D.P.; Howell, S.B. Preclinical efficacy and pharmacokinetics of AP5346, a novel diaminocyclohexane-platinum tumor-targeting drug delivery system. Clin. Cancer Res. 2006, 12, 2248-2254.

112. Li, C.; Ke, S.; Wu, Q.P.; Tansey, W.; Hunter, N.; Buchmiller, L.M.; Milas, L.; Charnsangavej, C.; Wallace, S. Tumor irradiation enhances the tumor-specific distribution of poly(L-glutamic acid)conjugated paclitaxel and its antitumor efficacy. Clin. Cancer Res. 2000, 6, 2829-2834.

113. Li, C.; Newman, R.A.; Wu, Q.P.; Ke, S.; Chen, W.; Hutto, T.; Kan, Z.; Brannan, M.D.; Charnsangavej, C.; Wallace, S. Biodistribution of paclitaxel and poly(L-glutamic acid)-paclitaxel conjugate in mice with ovarian OCa-1 tumor. Cancer Chemother. Pharmacol. 2000, 46, 416-422.

114. Sadekar, S.; Ray, A.; Janàt-Amsbury, M.; Peterson, C.M.; Ghandehari, H. Comparative biodistribution of PAMAM dendrimers and HPMA copolymers in ovarian-tumor-bearing mice. Biomacromolecules 2011, 12, 88-96.

115. Shiah, J.G.; Dvorák, M.; Kopecková, P.; Sun, Y.; Peterson, C.M.; Kopecek, J. Biodistribution and antitumour efficacy of long-circulating $N$-(2-hydroxypropyl)methacrylamide copolymer-doxorubicin conjugates in nude mice. Eur. J. Cancer 2001, 37, 131-139.

116. Eliasof, S.; Lazarus, D.; Peters, C.G.; Case, R.I.; Cole, R.O.; Hwang, J.; Schluep, T.; Chao, J.; Lin, J.; Yen, Y.; et al. Correlating preclinical animal studies and human clinical trials of a multifunctional, polymeric nanoparticle. Proc. Natl. Acad. Sci. USA 2013, 110, 15127-15132.

117. Kano, M.R.; Bae, Y.; Iwata, C.; Morishita, Y.; Yashiro, M.; Oka, M.; Fujii, T.; Komuro, A.; Kiyono, K.; Kaminishi, M.; et al. Improvement of cancer-targeting therapy, using nanocarriers for intractable solid tumors by inhibition of TGF-beta signaling. Proc. Natl. Acad. Sci. USA 2007, 104, 3460-3465.

118. Sarapa, N.; Britto, M.R.; Speed, W.; Jannuzzo, M.; Breda, M.; James, C.A.; Porro, M.; Rocchetti, M.; Wanders, A.; Mahteme, H.; et al. Assessment of normal and tumor tissue uptake of MAG-CPT, a polymer-bound prodrug of camptothecin, in patients undergoing elective surgery for colorectal carcinoma. Cancer Chemother. Pharmacol. 2003, 52, 424-430.

119. Chow, T.H.; Lin, Y.Y.; Hwang, J.J.; Wang, H.E.; Tseng, Y.L.; Wang, S.J.; Liu, R.S.; Lin, W.J.; Yang, C.S.; Ting, G. Improvement of biodistribution and therapeutic index via increase of polyethylene glycol on drug-carrying liposomes in an HT-29/lucxenografted mouse model. Anticancer Res. 2009, 29, 2111-2120.

120. Maeda, N.; Takeuchi, Y.; Takada, M.; Sadzuka, Y.; Namba, Y.; Oku, N. Anti-neovascular therapy by use of tumorneovasculature-targeted long-circulating liposome. J. Control. Release 2004, 100, 41-52.

121. Kwon, G.; Suwa, S.; Yokoyama, M.; Okano, T.; Sakurai, Y.; Kataoka, K. Enhanced tumour accumulation and prolonged circulation times of micelle-forming poly(ethylene oxide-aspartate) block copolymer-adriamycin conjugates. J. Control. Release 1994, 29, 17-23.

122. Schluep, T.; Cheng, J.; Khin, K.T.; Davis, M.E. Pharmacokinetics and biodistribution of the camptothecin-polymer conjugate IT-101 in rats and tumor-bearing mice. Cancer Chemother. Pharmacol. 2006, 57, 654-662. 
123. Conover, C.D.; Greenwald, R.B.; Pendri, A.; Gilbert, C.W.; Shum, K.L. Camptothecin delivery systems: Enhanced efficacy and tumour accumulation of camptothecin following its conjugation to polyethylene glycol via a glycine linker. Cancer Chemother. Pharmacol. 1998, 42, 407-414.

124. Deshan, Y.; Peng, P.; Dharap, S.S.; Wang, Y.; Mehlig, M.; Chandna, P.; Zhao, H.; Filpula, D.; Yang, K.; Borowski, V.; et al. Antitumor activity of poly(ethylene glycol)-camptothecin conjugate: The inhibition of tumor growth in vivo. J. Control. Release 2005, 110, 90-102.

125. Caiolfa, V.R.; Zamai, M.; Fiorino, A.; Frigerio, E.; Pellizzoni, C.; Argy, R.; Ghiglieri, A.; Castelli, M.G.; Farao, M.; Pesenti, E.; et al. Polymer-bound camptothecin: Initial biodistribution and antitumour activity studies. J. Control. Release 2000, 65, 105-119.

126. Hollis, C.P.; Weiss, H.L.; Leggas, M.; Evers, B.M.; Gemeinhart, R.A.; Li, T. Biodistribution and bioimaging studies of hybrid paclitaxel nanocrystals: Lessons learned of the EPR effect and image-guided drug delivery. J. Control. Release 2013, 172, 12-21.

127. Koukourakis, M.I.; Koukouraki, S.; Fezoulidis, I.; Kelekis, N.; Kyrias, G.; Archimandritis, S.; Karkavitsas, N. High intratumoural accumulation of stealth ${ }^{\circledR}$ liposomal doxorubicin (Caelyx ${ }^{\circledR}$ ) in glioblastomas and in metastatic brain tumours. Br. J. Cancer 2000, 83, 1281-1286.

128. Stapleton, S.; Allen, C.; Pintilie, M.; Jaffray, D.A. Tumour perfusion imaging predicts the intra-tumoral accumulation of liposomes. J. Control. Release 2013, 172, 351-357.

129. Greish, K.; Nagamitsu, A.; Fang, J.; Maeda, H. Copoly(styrene-maleic acid)-pirarubicin micelles: High tumor-targeting efficiency with little toxicity. Bioconjugate Chem. 2005, 16, 230-236.

130. Greish, K.; Sawa, T.; Fang, J.; Akaike, T.; Maeda, H. SMA-doxorubicin, a new polymeric micellar drug for effective targeting to solid tumours. J. Control. Release 2004, 97, 219-230.

131. Noguchi, Y.; Wu, J.; Duncan, R.; Strohalm, J.; Ulbrich, K.; Akaike, T.; Maeda, H. Early phase tumor accumulation of macromolecules: A great difference in clearance rate between tumor and normal tissues. Jpn. J. Cancer Res. 1998, 89, 307-314.

132. Kumazawa, E.; Ochi, Y. DE-310, a novel macromolecular carrier system for the camptothecin analog DX-8951f: Potent antitumor activities in various murine tumor models. Cancer Sci. 2004, $95,168-175$.

133. Seymour, L.W.; Miyamoto, Y.; Maeda, H.; Brereton, M.; Strohalm, J.; Ulbrich, K.; Duncan, R. Influence of molecular weight on passive tumour accumulation of a soluble macromolecular drug carrier. Eur. J. Cancer 1995, 31, 766-770.

134. Liu, T.-J.; Liu, S.; Hu, X.-L.; Sheng, S.-H.; Huang, Y.-B.; Jing, X.-B. EPR effect of amphiphilic copolymer micelles observed by fluorescent imaging. Chem. Res. Chin. Univ. 2011, 27, 628-634.

135. Iwai, K.; Maeda, H.; Konno, T. Use of oily contrast medium for selective drug targeting to tumor: Enhanced therapeutic effect and X-ray image. Cancer Res. 1984, 44, 2115-2121.

136. Iwai, K.; Maeda, H.; Konno, T.; Matsumura, Y.; Yamashita, R.; Yamasaki, K.; Hirayama, S.; Miyauchi, Y. Tumor targeting by arterial administration of lipids: Rabbit model with VX2 carcinoma in the liver. Anticancer Res. 1987, 7, 321-327.

137. Etrych, T.; Kovář, L.; Strohalm, J.; Chytil, P.; Ríhová, B.; Ulbrich, K. Biodegradable star HPMA polymer-drug conjugates: Biodegradability, distribution and anti-tumor efficacy. J. Control Release 2011, 154, 241-248. 
138. Heneweer, C.; Holland, J.P.; Divilov, V.; Carlin, S.; Lewi, J.S. Magnitude of enhanced permeability and retention effect in tumors with different phenotypes: 89Zr-albumin as a model system. J. Nucl. Med. 2011, 52, 625-633.

139. Borgman, M.P.; Aras, O.; Geyser-Stoops, S.; Sausville, E.A.; Ghandehari, H. Biodistribution of HPMA copolymer-aminohexylgeldanamycin-RGDfK conjugates for prostate cancer drug delivery. Mol. Pharm. 2009, 6, 1836-1847.

140. Lammers, T.; Kühnlein, R.; Kissel, M.; Subr, V.; Etrych, T.; Pola, R.; Pechar, M.; Ulbrich, K.; Storm, G.; Huber, P.; et al. Effect of physicochemical modification on the biodistribution and tumor accumulation of HPMA copolymers. J. Control. Release 2005, 110, 103-118.

141. Lammers, T.; Subr, V.; Peschke, P.; Kühnlein, R.; Hennink, W.E.; Ulbrich, K.; Kiessling, F.; Heimann, M.; Debus, J.; Huber, P.E.; et al. Image-guided and passively tumour-targeted polymeric nanomedicines for radiochemotherapy. Br. J. Cancer 2008, 99, 900-910.

(C) 2014 by the authors; licensee MDPI, Basel, Switzerland. This article is an open access article distributed under the terms and conditions of the Creative Commons Attribution license (http://creativecommons.org/licenses/by/3.0/). 